Georgetown University Law Center

Scholarship @ GEORGETOWN LAW

2003

\title{
The Global Reach of HIV/AIDS: Science, Politics, Economics, and Research
}

Lawrence O. Gostin

Georgetown University Law Center, gostin@law.georgetown.edu

This paper can be downloaded free of charge from:

https://scholarship.law.georgetown.edu/facpub/97

17 Emory Int'I L. Rev. 1-54 (2003)

This open-access article is brought to you by the Georgetown Law Library. Posted with permission of the author. Follow this and additional works at: https://scholarship.law.georgetown.edu/facpub

Part of the Health Law and Policy Commons, and the International Law Commons 


\title{
GEORGETOWN LAW Faculty Publications
}

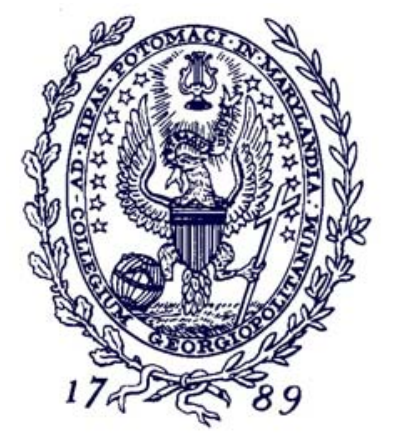

January 2010

\section{The Global Reach of HIV / AIDS: Science, Politics, Economics, and Research}

17 Emory Int'l L. Rev. 1-54 (2003)

\author{
Lawrence O. Gostin \\ Professor of Law \\ Georgetown University Law Center \\ gostin@law.georgetown.edu
}

This paper can be downloaded without charge from:

Scholarly Commons: http://scholarship.law.georgetown.edu/facpub/97/

SSRN: $\underline{\text { http: } / / \text { ssrn.com/abstract }=459343}$

Posted with permission of the author 


\title{
Articles
}

\section{THE GLOBAL REACH OF HIVIAIDS: SCIENCE, POLITICS, ECONOMICS, AND RESEARCH*}

\author{
Lawrence O. Gostin**
}

A constant theme in all our messages has been that, in this inter-dependent and globalized world, we have indeed again become the keepers of our brother and sister. That cannot be more graphically the case than in the common fight against HIV/AIDS.

Nelson Mandela, Former President of South Africa (2001).

HIV/AIDS affects people throughout the world-their health, their communities, and their countries' economic structures. It is truly a global epidemic, imposing a burden on all countries and regions, leaving none immune from its devastating impact. ${ }^{1}$ Forty-two million people are infected with HIV, with one-third of the cases among youth ages fifteen to twenty-four. ${ }^{3}$ Almost ninety percent of people

* This Article is taken from a chapter on the global HIV/AIDS pandemic in a forthcoming book, LAWRENCE O. GOSTIN, AIDS IN AMERICA: THE LIMITS OF TOLERANCE (University of North Carolina Press, forthcoming 2003). The author acknowledges the extraordinary assistance of Georgetown University Law Center law student Elizabeth Geddes.

** Lawrence O. Gostin is a Professor of Law at Georgetown University; Professor of Public Health, the Johns Hopkins University; Director, Center for Law and the Public's Health (CDC's Collaborating Center Promoting Health Through Law); and Research Scholar, Oxford University, Centre for Socio-Legal Studies.

1 See generally Bernhard Schwartlander et al., AIDS in a New Millennium, 289 SCI. 64 passim (2000) (providing statistics demonstrating the pandemic nature of AIDS).

2 UNAIDS \& WORLD HEALTH ORG., AIDS EPIDEMIC UPDATE 3 (2002), available at http://www.unaids.org/worldaidsday/2002/press/update/epiupdate2002_en.doc (last visited Apr. 7, 2003) [hereinafter AIDS EPIDEMIC UPDATE 2002].

3 UNITED NATIONS ChILDREN'S Fund (UNICEF), UNAIDS, \& WHO, YounG PEOPLE AND HIV/AIDS: OPPORTUNITY IN CRISIS (2002) Thereinafter UNICEF, UNAIDS \& WHO]; TODD SUMMERS ET AL., THE TIP OF THE ICEBERG: THE GLOBAL IMPACT OF HIV/AIDS ON YOUTH 3 (2002), available at http://www.kff.org/ 
living with HIV/AIDS live in developing countries, ${ }^{4}$ which can least afford the sickness, death, and loss of productivity associated with the epidemic (See Map 1).

content/2002/6043/6043v3.pdf (last visited Apr. 14, 2003).

4 UNAIDS \& THE WORLD BANK, HIV aND HUMAN DEVElopment: THE DEVASTATING IMPACT OF AIDS 3 (1999). 
Map 1: Adults and children estimated to be living with HIV/AIDS as of the end of $2002 *$

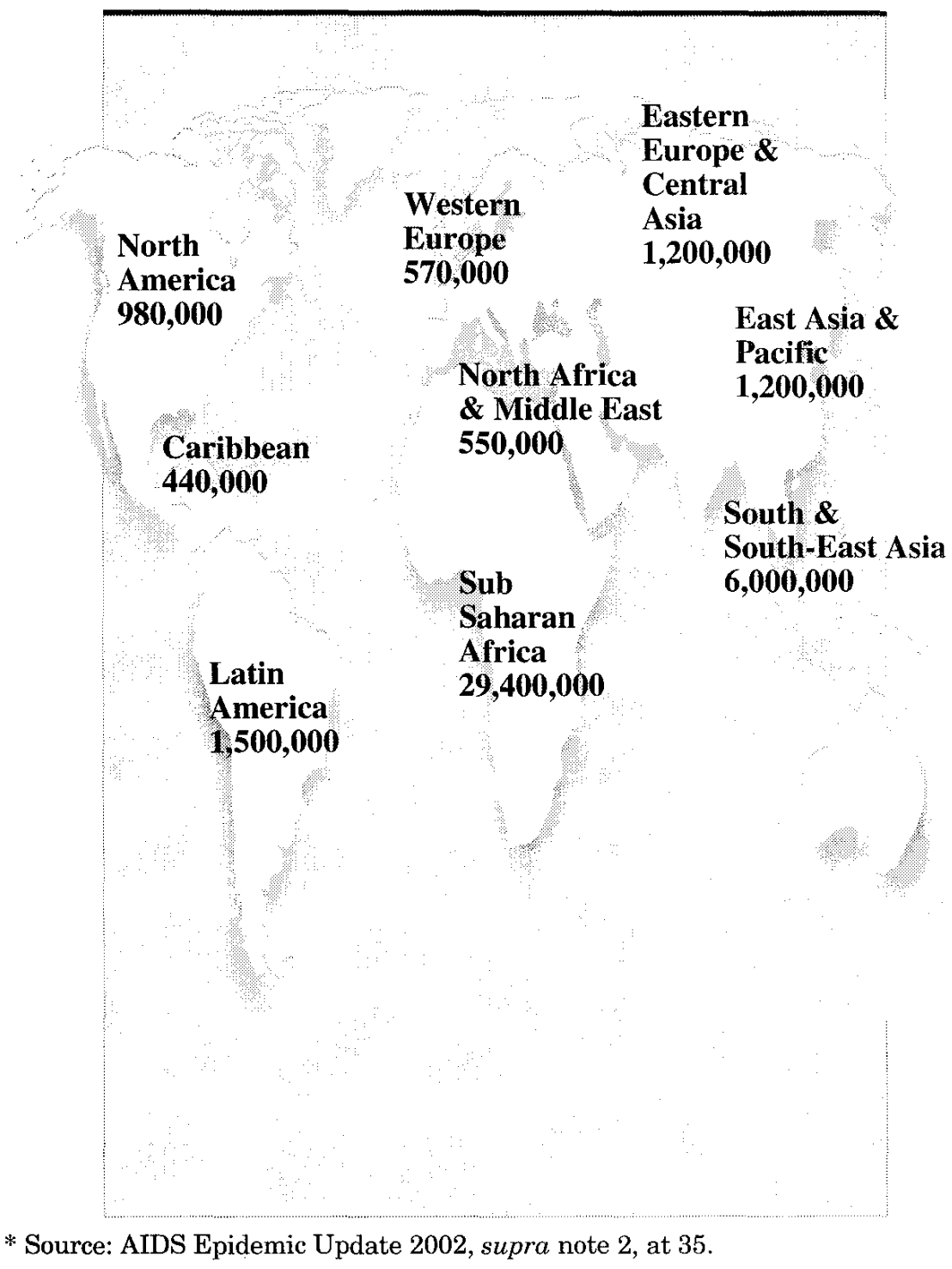

If the current trend continues, there will be 100 million people infected with HIV by 2006, thereby becoming the worst pandemic since the Black Death swept through Europe in the fourteenth century and killed one in four 
people. ${ }^{5}$ In 2002 alone, three million people died from AIDS. ${ }^{6}$ More than twenty million people have already died from AIDS since it was first identified in the early $1980 \mathrm{~s}^{7}$ (See Map 2).

\footnotetext{
${ }^{5}$ David F. Gordon, The Next Wave of HIV/AIDS: Nigeria, Ethiopia, Russia, India, and China, National Intelligence Council 10 (Sept. 2002) (projecting 75 million cases of HIV in five of the world's most populous countries by 2010), available http:/www.cia.gov/nic/pubs/other_products/ICA\%20HIVAIDS\%20unclassified\%2009 2302POSTGERBER.pdf (last visited Apr. 10, 2003); John Donnelly, World's AIDS Crisis Worsening: Report Says Disease Spreading Fast in Sub-Saharan Africa, BOSTON GLOBE, June 15, 2002, at A1 (stating that approximately twenty-three million people have died from the disease-far more than even Europe's Black Death in the fourteenth century); AIDS EPIDEMIC UPDATE 2002, supra note 2, at 5.

6 AIDS EPIDEMIC UPDATE 2002, supra note 2, at 4.

7 Centers for Disease Control \& Prevention, The Global HIV and AIDS Epidemic, 2001, 50 MORBIDITY \& MORTALITY WKLY. REP. 434, 434 (2001).
} 
Map 2: Adults and children estimated to be newly infected with HIV in 2002 *

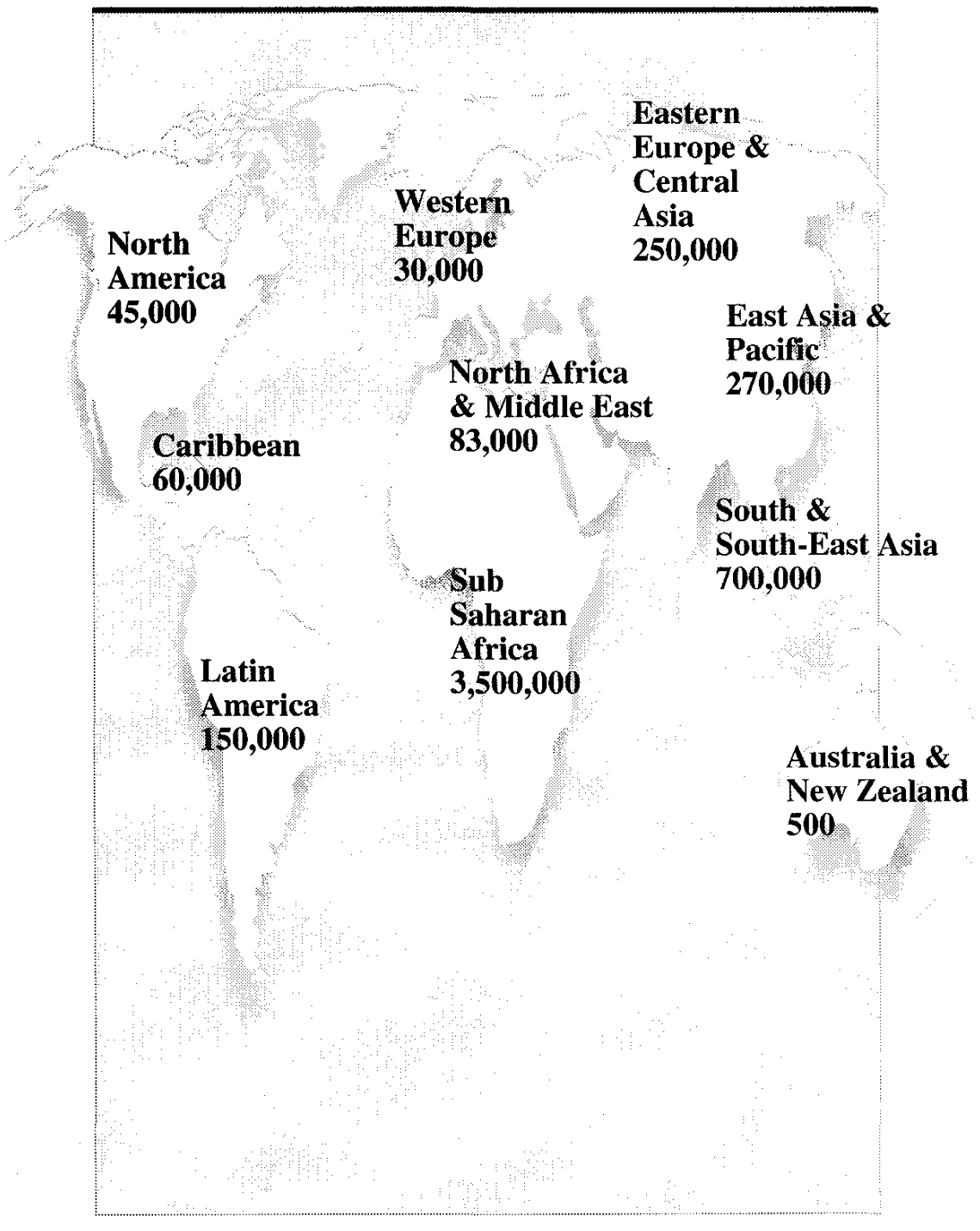

* Source: AIDS EPIDEMIC UPDATE 2002, supra note 2, at 34. 
The impact of HIV/AIDS is evident in regions around the world (See Table 1). The African continent has experienced the greatest burden of disease. For example, in Botswana, the country which has the highest prevalence of HIV, almost forty percent of its adult population is infected. ${ }^{8}$ The average life expectancy in Botswana is now below forty years for the first time since $1950 .^{9}$ As a result of the AIDS epidemic, the average life expectancy in southern Africa is expected to drop to under thirty years of age by $2010^{10}$ (See Figure 1). The fastest growing rate of HIV infection is in Russia. ${ }^{11}$ In Russia alone, HIV has increased fifteen-fold in the last three years. ${ }^{12}$ In China, the world's most populous country, the government acknowledged that 600,000 to one million people are living with HIV/AIDS; only four percent of the adults there, however, even know how HIV is contracted and spread. ${ }^{13}$

\footnotetext{
${ }^{8}$ Liz McGregor, Botswana Battles Against 'Extinction,' THE GUARDIAN, July 8 , 2002 , at 12 .

Id.

10 Karen A. Stanecki, U.S. Census Bureau, The AIDS Pandemic In the 21St CENTURY 11 (2002).

${ }^{11}$ AIDS EPIDEMIC UPDATE 2002, supra note 2, at 12.

12 Id.

13 Elisabeth Rosenthal, With Ignorance as the Fuel, AIDS Speeds Across China, N.Y. TIMES, Dec. 30, 2001, at A1. See Schwartlander, supra note 1, at 64.
} 
Table 1:

Regional HIV/AIDS Statistics and Features*

\begin{tabular}{|l|l|c|c|c|c|l|}
\hline \multicolumn{1}{|c|}{ Region } & $\begin{array}{c}\text { Epidemic } \\
\text { Started }\end{array}$ & $\begin{array}{c}\text { Adults \& } \\
\text { Children } \\
\text { living with } \\
\text { HIV/AIDS }\end{array}$ & $\begin{array}{c}\text { Adults \& } \\
\text { Children } \\
\text { newly } \\
\text { infected } \\
\text { with } \\
\text { HIV/AIDS }\end{array}$ & $\begin{array}{c}\text { Adult } \\
\text { Prevalence } \\
\text { Rate }\end{array}$ & $\begin{array}{c}\text { \% of } \\
\text { HIV- } \\
\text { positive } \\
\text { adults } \\
\text { who are } \\
\text { women }\end{array}$ & $\begin{array}{c}\text { Main modes of } \\
\text { transmission for } \\
\text { lhose who are } \\
\text { HIV/AID with }\end{array}$ \\
\hline $\begin{array}{l}\text { Sub-Saharan } \\
\text { Africa }\end{array}$ & $\begin{array}{l}\text { late 70s } \\
\text { early 80s }\end{array}$ & 28.1 million & 3.4 million & $8.4 \%$ & $55 \%$ & Hetero \\
\hline $\begin{array}{l}\text { North Africa } \\
\text { \& } \\
\text { Middle East }\end{array}$ & late 80s & 440,000 & 80,000 & $0.2 \%$ & $40 \%$ & Hetero, IDU \\
\hline $\begin{array}{l}\text { South \& } \\
\text { South-East } \\
\text { Asia }\end{array}$ & late 80s & 6.1 million & 800,000 & $0.6 \%$ & $35 \%$ & Hetero, IDU \\
\hline $\begin{array}{l}\text { East Asia \& } \\
\text { Pacific }\end{array}$ & late 80s & 1 million & 270,000 & $0.1 \%$ & $20 \%$ & $\begin{array}{l}\text { IDU, Hetero, } \\
\text { MSM }\end{array}$ \\
\hline $\begin{array}{l}\text { Latin } \\
\text { America }\end{array}$ & $\begin{array}{l}\text { late 70s } \\
\text { early 80s }\end{array}$ & 1.4 million & 130,000 & $0.5 \%$ & $30 \%$ & $\begin{array}{l}\text { MSM, IDU, } \\
\text { Hetero }\end{array}$ \\
\hline Caribbean & $\begin{array}{l}\text { late 70s } \\
\text { early 80s }\end{array}$ & 420,000 & 60,000 & $2.2 \%$ & $50 \%$ & Hetero, MSM \\
\hline $\begin{array}{l}\text { Eastern } \\
\text { Europe \& } \\
\text { Central Asia }\end{array}$ & early 90s & 1 million & 250,000 & $0.5 \%$ & $20 \%$ & IDU \\
\hline $\begin{array}{l}\text { Western } \\
\text { Europe }\end{array}$ & $\begin{array}{l}\text { late 70s } \\
\text { early 80s }\end{array}$ & 560,000 & 30,000 & $0.3 \%$ & $25 \%$ & MSM, IDU \\
\hline $\begin{array}{l}\text { North } \\
\text { America }\end{array}$ & late 70s & 940,000 & 45,000 & $0.6 \%$ & $20 \%$ & $\begin{array}{l}\text { MSM, IDU, } \\
\text { Hetero }\end{array}$ \\
\hline $\begin{array}{l}\text { Australia \& } \\
\text { New Zealand }\end{array}$ & $\begin{array}{l}\text { late 70s } \\
\text { early 80s }\end{array}$ & 15,000 & 500 & $0.1 \%$ & $10 \%$ & MSM \\
\hline TOTAL & 40 million & 5 million & $1.2 \%$ & $48 \%$ & \\
\hline
\end{tabular}

** Hetero = heterosexual transmission; IDU = transmission through injection drug use; $M S M=$ sexual transmission among men who have sex with men.

* Source: AIDS EPIDEMIC UPDATE 2002, supra note 2, at 6. 
Figure 1:

Deaths from AIDS and People Using Antiretroviral Drugs*

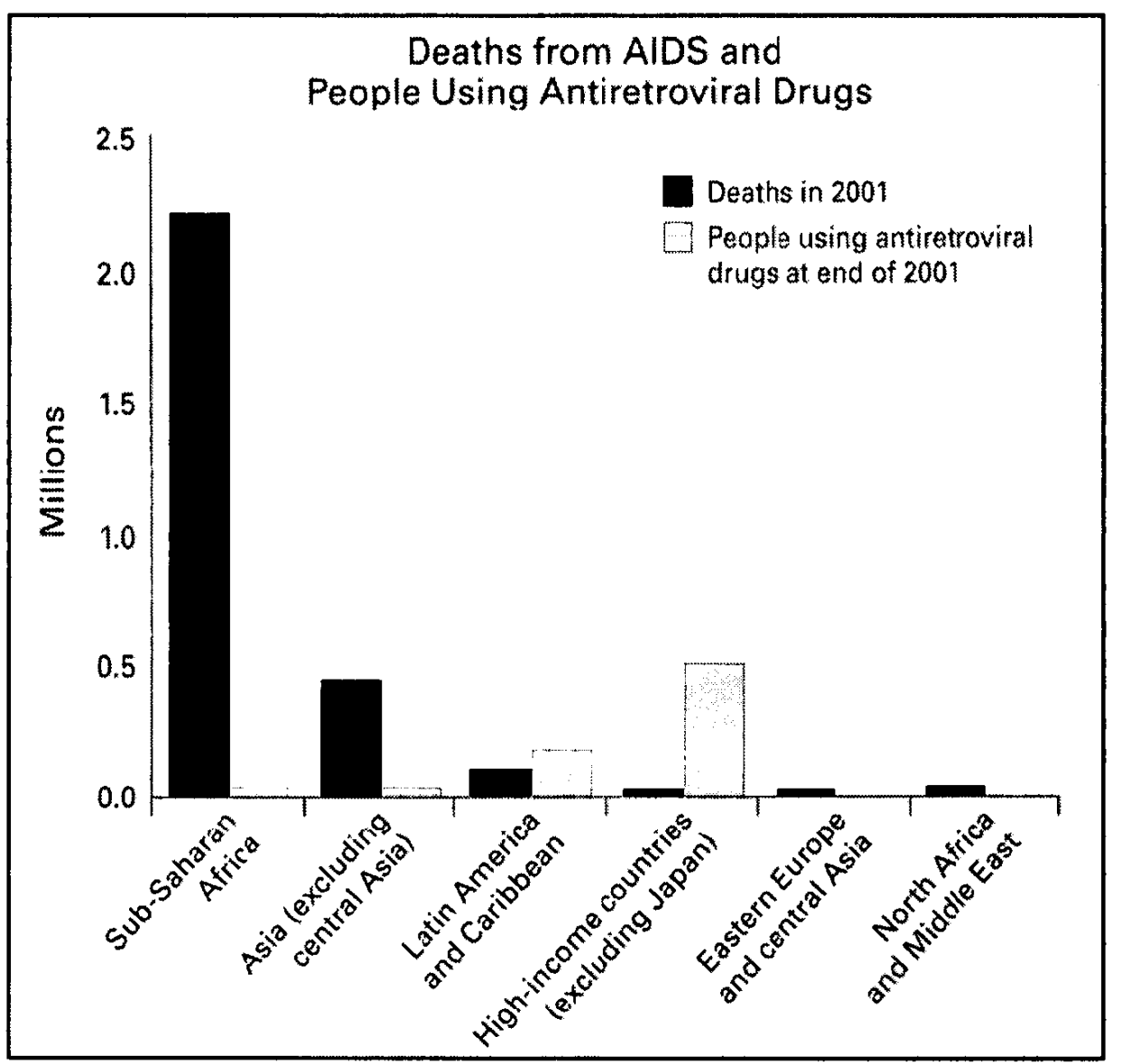

* Source: Robert Steinbrook, Beyond Barcelona-The Global Response, 347 NEW ENG. J. MED. 553, 553 (2002). 
The epic tragedy of HIV/AIDS in Africa and the tragedy unfolding in other regions is exacerbated by "simultaneous catastrophes": famine and armed conflict. ${ }^{14}$ In Africa, the AIDS epidemic, coupled with famine, ${ }^{15}$ has sapped the strength and eroded the skills of land workers, retarded agricultural production, and reduced rural livelihoods. ${ }^{16}$ Additionally, people suffering from AIDS require more food. Nutritional requirements for entire communities have increased as a result of rampant HIV/AIDS infection. ${ }^{17}$ War and civil strife also contribute to the tragedy of AIDS. ${ }^{18}$ Populations at war are often subjected to human rights abuses, conditions of poverty and mass displacement. ${ }^{19}$ One of the most prevalent human rights abuses in nations at war is sexual violence. ${ }^{20}$ Conditions of poverty might lead people to engage in commercial sex to survive. The massive displacements of people are associated with disruption of social cohesion and relationships, fostering promiscuity and commercial sex. ${ }^{21}$ Large population movements, moreover, facilitate the geographic spread of HIV infection. ${ }^{22}$

Societies are fundamentally altered as a result of HIV/AIDS penetrating through various populations: HIV/AIDS among young adults weakens the labor force and destabilizes the economy; ${ }^{23}$ HIV/AIDS among mothers and

${ }^{14}$ Kofi A. Annan, Editorial, In Africa, AIDS Has a Woman's Face, N.Y. Times, Dec. 29, 2002, § 4, at 9 (stating that millions of African women are threatened by two simultaneous catastrophes: famine and AIDS).

${ }^{15}$ At least thirty million people are at risk of starvation in southern Africa and the Horn of Africa. Id.

${ }^{16} I d$.

17 Peter Piot, Editorial, Fighting Aids with a Sound Investment, WASH. POST, Nov. 27, 2002, at A17.

18 AIDS EPIDEMIC UPDATE 2002, supra note 2, at 35.

19 Id.

${ }^{20}$ See id. (noting that in the Balkan conflict, 30,000 to 40,000 women were raped).

${ }^{21}$ Id. (noting that almost ten percent of women who had been displaced as a result of armed conflict in Sierra Leone had been sexually assaulted).

${ }^{22}$ Anne Buve et al., The Spread and Effect of HIV-1 Infection in Sub-Saharan Africa, 359 LANCET 2011, 2015 (2002).

${ }^{23}$ Thomas C. Quinn, Global Burden of the HIV Pandemic, 348 LANCET 99, 101 
[Vol. 17

fathers creates parentless children and dislocated families; ${ }^{24}$ HIV/AIDS among infants and youth diminishes hope and possibilities for the future. ${ }^{25}$ In short, the pandemic destroys families and social networks, diminishes economic growth, and creates a sense of pessimism about the future. ${ }^{26}$

The security of countries and regions is affected because HIV/AIDS can have a destabilizing effect on society. HIV/AIDS creates poverty, a sense of vulnerability and hopelessness that feeds conditions leading to feuds, violence, and dislocation. In turn, wars and armed conflict exacerbate conditions of poverty, powerlessness, and social instability, all of which facilitate HIV transmission. ${ }^{27}$ A healthier, more prosperous, and stable Third World would experience fewer conflicts and disasters. ${ }^{28}$

In recognition of these substantial harms, the United States has declared HIV/AIDS a threat to national security. ${ }^{29}$ The strength of American sentiment was clear in the words of U.S. Secretary of State, Colin Powell, stating

(1996).

${ }^{24}$ The orphan crisis has grown considerably, changing the landscape of the family, particularly in sub-Saharan Africa. More than thirteen million children under age fifteen have lost one or both parents to AIDS. By 2010, this number is expected to grow to twenty-five million. Governments and international agencies have remained somewhat complacent in the face of this crisis, perhaps due to the traditional African social system which has absorbed many of the most vulnerable children. UNAIDS, UNICEF, \& U.S. AGENCY FOR INTERNATIONAL DEVELOPMENT, CHILDREN ON THE BRINK 2002: A JOINT REPORT ON ORPHAN ESTIMATES AND PROGRAM STRATEGIES 3 (2002) [hereinafter CHILDREN ON THE BRINK]; Geoff Foster, Supporting Community Efforts to Assist Orphans in Africa, 346 NEW ENG. J. MED. 1907, 1907 (2002).

${ }_{25}^{25}$ See CHILDREN ON THE BRINK, supra note 24 , at 3.

${ }^{26}$ UNAIDS \& WORLD BANK, HIV AND HUMAN DEVELopment: The DEVASTATING IMPACT OF AIDS (1998), at 6-7 [hereinafter HIV AND HUMAN DEVELOPMENT: THE DEVASTATING IMPACT OF AIDS]; UNAIDS, GUIDELINES FOR STUDIES OF THE SOCIAL AND ECONOMIC IMPACT OF HIV/AIDS, at 9 (2000), available at http://www.unaids.org/publications/documents/economics/costeffec/JC326-Guidelines .pdf (last visited Apr. 7, 2003).

${ }^{27}$ AIDS EPIDEMIC UPDATE 2002, supra note 2, at 35.

28 Editorial, Health Aid for Poor Countries, N.Y. TIMES, Jan. 3, 2002, at A22.

29 Barton Gellman, AIDS is Declared Threat to Security, WASH. POST, Apr. 30, 2000 , at $\mathrm{A} 1$. 
that: "I was a soldier and I know of no enemy in war more insidious or vicious than AIDS, an enemy that poses a clear and present danger to the world." ${ }^{30}$

Prevention of HIV/AIDS would benefit all regions and countries, irrespective of the prevalence or incidence of HIV/AIDS in the population as all social and economic life in the early twenty-first century is interconnected. HIV/AIDS in one part of the world is bound to affect the health, economy, and security of countries everywhere. The health of all people is affected by modern travel and migration patterns. HIV/AIDS, and the interconnected epidemics of tuberculosis, sexually transmitted diseases, and drug dependency, can spread across countries and regions. ${ }^{31}$ The economy of all countries is affected because of the complex economic and trade relationships that exist within the modern world. Countries and regions with a heavy burden of HIV/AIDS often have weaker economies, impeding their ability to import and export essential products and services. ${ }^{32}$ This has a cascading effect on the economies of other countries.

3o Colin Powell, Remarks at the United Nations General Assembly Special Session on HIV/AIDS: Opening Session, at 46 (June 25, 2001), available at http://www.kaisernetwork.org/health_cast/uploaded_files/ACF427.pdf (last visited Apr. 10, 2003).

${ }^{31}$ Kevin M. De Cock \& Robert S. Janssen, An Unequal Epidemic in an Unequal World, 288 JAMA 236, 237 (2002).

${ }^{32}$ See, e.g., INT'L LAB. ORG., HIV/AIDS IN AFRICA: THE IMPACT ON THE WORLD OF WORK (noting that deaths and disabilities caused by AIDS are eroding the workforce and estimating that in countries where AIDS incidence is greater than five percent, national income will be chilled), at http://www.ilo.org/public/english/protection /trav/aids/download/pdf/adforange.pdf (last visited Mar. 18, 2003). 
Given the undeniable global effects of HIV/AIDS, one might expect the international community to unite in an effort to reach the common goal of preventing and treating HIV/AIDS. In June 2001, the United Nations General Assembly adopted by consensus the Declaration of Commitment on HIV/AIDS: "Global Crisis-Global Action." In the Declaration, 189 governments pledged to reduce HIV prevalence among young people by twenty-five percent in the worst affected countries by 2005 and globally by $2010 .^{34}$ International organizations, such as UNAIDS, ${ }^{35}$ the World Health Organization (WHO), ${ }^{36}$ and the World Bank, ${ }^{37}$ have also issued warnings and calls for action (See Figure 2).

33 See generally DECLARATION OF COMMITMENT ON HIV/AIDS, UNITED NATIONS GENERAL ASSEMBLY SPECIAL SESSION ON HIV/AIDS (2001), available at http://www.unaids.org/UNGASS/docs/AIDSDeclaration_en.pdf (last visited Mar. 15, 2003).

${ }^{34}$ See generally id.

${ }^{35}$ See AIDS EPIDEMIC UPDATE 2002, supra note 2 passim; HIV AND HUMAN DEVELOPMENT: THE DEVASTATING IMPACT OF AIDS, supra note 26, at 6-7; UNAIDS, GUIDELINES FOR STUDIES OF THE SOCIAL AND ECONOMIC IMPACT OF HIV/AIDS, supra note 26 , at 9.

${ }^{36}$ See THE World Health ORganization, Commission on MaCroeconomics AND HEALTH passim (2001).

${ }^{37}$ See WORLD BANK, CONFronting AIDS: PUBlic Priorities IN A Global EPIDEMIC passim (1997) [hereinafter CONFRONTING AIDS]. 
Figure 2: The HIV/AIDS Epidemic Timeline*

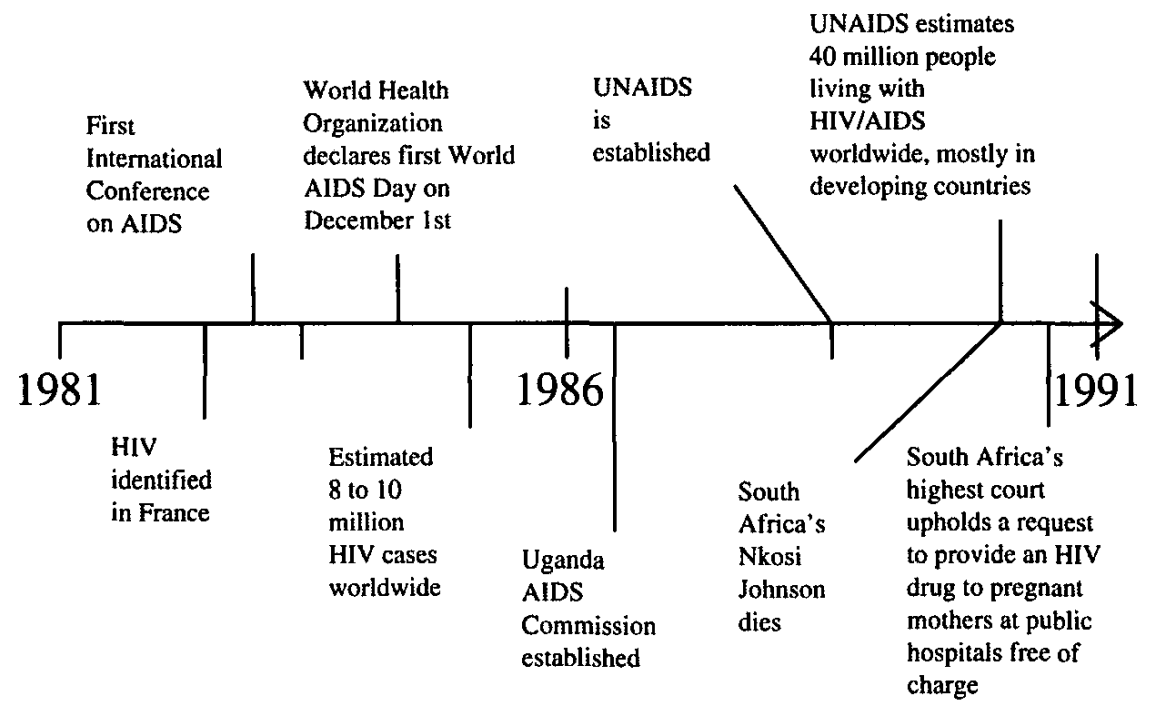

*Source: Adapted from timelines prepared by the Kaiser Foundation and American Medical Student Association

Yet, the responses by governments to the HIV/AIDS pandemic have been fragmented. There is often an absence of political will, an unwillingness to share strategies and resources, and wide philosophical and pragmatic differences, principally among countries in the North/West and those in the South/East. ${ }^{38}$ This unwillingness to cooperate is caused, in part, by insular attitudes toward world health, economics, and politics. There is a certain narrow self-interest that seems to prevent many countries from engaging in truly global cooperative approaches. The unwillingness to cooperate may also be due to the fact that resource-rich and resource-poor countries have markedly

${ }^{38}$ See De Cock \& Janssen, supra note 31, at 237. 
different priorities tailored to the different dynamics of the epidemic in their regions. ${ }^{39}$

This Article examines the major social, political, economic, and ethical issues involved in the global HIV pandemic. First, it examines the steps needed to prevent and treat HIV effectively and examines why many leaders have not responded more forcefully. This Part discusses the intangible, but crucial, aspect of political will. ${ }^{40}$ Second, this Article looks at the divisive issue of drugs, patents, and international trade law. Highly developed countries usually want to uphold the patent system to protect the proprietary interests of drug companies, which keeps the price of HIV/AIDS drugs high, placing them out of the reach of resource-poor countries. Finally, this Article examines the vexing issue of research ethics. The research community has struggled with one overriding question in international collaborative investigations: Should the ethical standards held in developed countries apply when engaging in research in less developed countries? Stakeholders are at odds and struggle to find the balance between ensuring strong ethical standards and expediting access to cost-effective treatments in poor countries.

\section{SCIENCE, Politics, AND MONEY: Understanding THE PROBLEM AND WORKING TOWARD A SOLUTION}

Individually, we must demonstrate the qualities of courage, integrity and respect for others. Collectively, our governments must recognize that leadership means abandoning rhetoric and taking action. They

See Quinn, supra note 23 passim.

40 Carmen PEREz-Casas, HIV/AIDS Medicines Pricing RePort 1 (2000), available at http:/www.accessmed-sf.org/upload/ReportsandPublications/ 49200113585/Duban\%20report\%20update\%20dec\%202000.pdf (last visited Mar. 15, 2003). 
must energize our people and mobilize the necessary resources to conduct the campaign against HIV/AIDS.

Graça Machel, African Development Forum (2000).

National governments have unique responsibilities for preventing and treating HIV/AIDS and mitigating its public health and economic effects. Only governments have the means and mandate to provide for "public goods" services that benefit society but that the market will not provide due to insufficient incentives. ${ }^{41}$ The role of the government is to advance the well-being of its citizens and promote a fair distribution of social benefits. Governments, acting for the people, should adopt the most effective strategies and marshal the resources needed to reduce the burden of the epidemic.

Most importantly, governments should act as soon as possible. As Dr. Peter Piot, UNAIDS Executive Director, told an audience at the Fourteenth International AIDS Conference, "It is now clear that the AIDS epidemic is still in its early stages. And let us be equally clear: our fight back is at an even earlier stage." ${ }^{\prime 42}$ Nearly half the world's population lives in areas where HIV is rare. ${ }^{43}$ Investments in prevention and education at the earliest stages of an epidemic are the least expensive and most effective actions available to a government. ${ }^{44}$ Decisive action could have saved countless lives in populous countries such as India ${ }^{45}$

41 ConFronTING AIDS, supra note 37, at 40.

42 Press Release, UNAIDS, UNAIDS Executive Director Says AIDS Battle Must be Fought on the Global Political Stage (July 7, 2002), available at http://www.unaids.org/whatsnew/press/eng/pressarc02/Barcelona_070702.html (last visited Mar. 15, 2003).

${ }^{43}$ ConFronTING AIDS, supra note 37, at 7. For example, the adult infection prevalence in North Africa and the Middle East was 0.3 percent at the end of 2002 and in East Asia and the Pacific, the proportion of infected adults was a mere 0.1 percent. AIDS EPIDEMIC UPDATE 2002, supra note 2, at 6.

${ }^{44}$ Confronting AIDS, supra note 37 , at 7.

${ }^{45}$ Kevin M. De Cock \& Helen A. Weiss, The Global Epidemiology of HIV/AIDS, 5 TROPICAL MED. \& INT'L HEALTH A3, A8 (2000). 
and South Africa. ${ }^{46}$ It could still save lives in China, Russia, and other regions where poverty and lack of education lead to drug use and the spread of disease. ${ }^{47}$

The public health community has long agreed on the appropriate response to HIV/AIDS. ${ }^{48}$ For instance, unified strategies directed at youth focus on empowerment and education ${ }^{49}$ (See Table 2). While strategies vary according to local conditions and cultures, the need for surveillance, prevention, treatment, and protection of human rights are the same everywhere.

Table 2:

Ten Step Strategy for HIV Prevention Among Youth*

1. End the Silence, Stigma and Shame

2. Provide Young People with Knowledge and Information

3. Equip Young People with Life Skills to Put Knowledge Into Practice

4. Provide Youth-Friendly Health Services

5. Promote Voluntary and Confidential HIV Counseling and Testing

6. Work with Young People, Promote Their Participation

7. Engage Young People Who are Living with HIV/AIDS

8. Create Safe and Supportive Environments

9. Reach Out to Young People Most At Risk

10. Strengthen Partnerships, Monitor Progress

*Source: UNICEF, UNAIDS \& WHO, supra note 3, at 25-36.

${ }^{48}$ See generally Donald G. McNeil, Jr., AIDS and Death Hold No Sting for Fatalistic Men at African Bar, N.Y. TIMES, Nov. 29, 2001, at A14 (noting that "poverty and ignorance about health run so deep").

${ }^{47}$ See Elisabeth Rosenthal, A Poor Ethnic Enclave in China is Shadowed by Drugs and HIV, N.Y. TIMES, Dec. 21, 2001, at A1; Rosenthal, supra note 13. tbl. 2)

See, e.g., UNICEF, UNAIDS \& WHO, supra note 3, at 25-36 (reprinted infra, Id. 
Public health authorities cannot develop the most appropriate policies for prevention and treatment without accurate data about the prevalence and incidence of HIV/AIDS in the general population and within specific communities. ${ }^{50} \quad$ Through comprehensive screening, reporting, and active surveillance, policy makers can ascertain the scope and direction of the epidemic in their country. ${ }^{51}$ Surveillance provides clear information about the growing burden of HIV/AIDS on women, youth, and ethnic minorities, and within groups at heightened risk in the society, such as homosexuals, injection drug users, and sex workers. ${ }^{52}$ The information gathered can then be used to assist groups most affected by the disease.

Understanding the risks and realities of HIV/AIDS is a necessary precursor to behavior change. ${ }^{53}$ Accordingly, disseminating information to the public about health risks is vital. It is crucial that individuals understand the methods of contracting and transmitting HIV. This should include education, counseling, and other methods of targeted health promotion. Educational messages should target the specific needs of individuals and groups. AIDS education should be culturally and linguistically appropriate, but sufficiently explicit to convey the information clearly.

Societal prohibitions must not thwart AIDS education. For example, educational materials targeted at gay men should not avoid a graphic discussion of risky behaviors as a concession to the wider population's moral beliefs. In certain communities, there may also be a pervasive culture

${ }^{50}$ See generally Lawrence O. Gostin et al., National HIV Case Reporting for the United States-A Defining Moment in the History of the Epidemic, 337 NEW. ENG. J. MED 1162, 1162-64 (1997).

${ }^{51}$ See id. at 1163-64.

${ }^{52} I d$. at 1163 .

53 See generally THE WORLd BANK, EDUCATION AND HIV/AIDS, A WINDOW OF HOPE xvii, 5 (2002) (noting that education is a "proven means to prevent HIV/AIDS"), available at http://www1.worldbank.org/education/pdf/Ed\%20\&\%20 HIV_AIDS\% 20cover\%20print.pdf (last visited Mar. 20, 2003). 
of silence that excludes discussion of HIV/AIDS. A brave action to break this silence took place at the Thirteenth International AIDS Conference in Durban, South Africa, where Nkosi Johnson, a boy living with HIV/AIDS, criticized his President for neglecting the epidemic in South Africa $^{54}$ Advocates and role models like Johnson are instrumental in raising awareness about HIV/AIDS and highlighting government denial of the true facts of the epidemic.

Even when the risks of certain behaviors may be understood, eliminating risky activity is not always possible or realistic. While experience demonstrates that prohibition messages (e.g., "just say no") are not effective because individuals will continue to engage in risky behaviors, ${ }^{55}$ harm reduction strategies have been shown to be effective in reducing risky behaviors. ${ }^{56}$ Harm reduction strategies are those that provide individuals at risk with the means to protect themselves, such as condoms or sterile drug injection equipment. ${ }^{57}$

The public health strategies discussed above are insufficient to reduce the burden of HIV/AIDS unless people are empowered to protect their health. One of the primary strategies in the fight against HIV/AIDS is to safeguard the human rights of those who are at risk of infection or are infected. Girls and women are especially vulnerable. While they may understand the risks and have access to condoms,

${ }^{54}$ Belinda Beresford, Nkosi Johnson: Child Who Became the Campaigning Face of AIDS in South Africa, THE GUARDIAN, June 2, 2001, at 22, available at http://www.guardian.co.uk/aids/story/0,7369,500309,00.html (last visited Mar. 15, 2003).

${ }^{56}$ Douglas Kirby, Do Abstinence-Only Programs Delay the Initiation of Sex Among Young People and Reduce Teen Pregnancy? NAT'L CAMPAIGN TO PREVENT TEEN PREGNANCY 5 (2002) available at http://www.teenpregnancy.org/ resources/data/pdf/abstinence_eval.pdf (last visited Apr. 5, 2003).

${ }^{56}$ See Scott Burris et al., Harm Reduction in the Health Care System: The Legality of Prescribing and Dispensing Syringes to Drug Users, 11 HEALTH MATRIX $5,12-13(2001)$.

${ }^{57}$ See generally id. at 5-7. 
they may not be able to control safer sex practices. ${ }^{58}$ Women's relationships may be controlled by violence, cultural expectations, or economic dependence. When a woman's husband leaves her or dies, women may be deprived of credit, distribution networks, or land rights. ${ }^{59}$ Improving the status of women and strengthening their social, political, and economic rights would allow them to protect themselves against HIV and other health threats. ${ }^{60}$

Because prevention of HIV infection is not always possible, government policies should address both prevention and post-infection health care. Individuals can lead healthier and longer lives if they receive treatment for HIV. ${ }^{61}$ Health care can alleviate symptoms and reduce the likelihood of opportunistic infections. As President William J. Clinton observed, "[h]istorians will look back on our time and see that our civilization spends many millions of dollars educating people about the scourge of H.I.V. . . B But what they will find not so civilized is our failure to treat ninetyfive percent of people with the disease." ${ }^{\prime 62}$ In July 2002, the United Nations High Commissioner for Human Rights (UNHCHR) and UNAIDS developed updated guidelines on HIV/AIDS and human rights, which declared that access to HIV/AIDS treatment is fundamental to realizing the right to health and that access to medication is one element of a comprehensive program of prevention, treatment, care, and support. ${ }^{63}$

\footnotetext{
${ }^{58}$ See generally Donald G. McNeil, Jr., Rare Condoms, Deadly Odds for TruckStop Prostitutes, N.Y. Times, Nov. 29, 2001, at A14.

Annan, supra note 14, §4, at 9.

${ }^{60}$ See Quinn, supra note 23, at 101, 105.

${ }^{61}$ CENTERS FOR Disease CONTROL AND PREvention, National AIDS SURVEILLANCE DATA 2, available at http://www.cdc.gov/hiv/graphics/images/ 1285/1285-6.pdf (last visited Apr. 10, 2003); J.T. King, Jr. et al., Long-Term HIV/AIDS Survival Estimation in the Highly Active Antiretroviral Therapy Era, 23 MED. DECISION MAKING 9 (2003).

${ }^{62}$ William Jefferson Clinton, AIDS is Not a Death Sentence, N.Y. TIMES, Dec. 1, 2002 , at D9.

${ }^{63}$ See Office of the U.N. High Comm'r for Human Rights \& the Joint U.N. Programme on HIV/AIDS, HIV/AIDS and Human Rights Guidelines 6 (2002), at 13,
} 


\section{A. The Impact of Political Will}

"Above all, the challenge of AIDS is a test of leadership." The strategies for prevention and treatment of HIV/AIDS are well accepted and have been used in practice in countries as varied as Senegal, Thailand, Uganda, Brazil, Zambia, and Cambodia. For example, Uganda, with limited access to high technology medicine, has reduced the average national prevalence of HIV among adults from around $18.5 \%$ in 1995 to $8.3 \%$ at the end of $1999 .^{65}$ The government of Uganda's response to the epidemic dates back to 1986 when the first AIDS Control Programme was created in the Ministry of Health. ${ }^{66}$ The Uganda AIDS Commission (UAC) was instituted in 1992 and placed under the Office of the President. ${ }^{67}$ The UAC created an atmosphere of openness and effective political commitment to HIV/AIDS control which has created high levels of public awareness about the dangers of the epidemic and means of prevention. $^{68}$

A similar picture of success can be found in Senegal where the government acted rapidly to develop a national program to prevent HIV, beginning with systematic bloodscreening in $1986{ }^{69}$ The government in Dakar, Senegal was

HR/PUB/2002/1 (2002).

${ }_{64}$ Kofi A. Annan, The Secretary-General Address to the African Development Forum in Addis Ababa, (Dec. 7, 2000), available at http://www.uneca.org/ adf2000/daily_updates/speeches_and_press_releases/120700address_kofi_annan.htm (last visited Mar. 15, 2003).

${ }_{65}^{6}$ UGANDA AIDS COMM'N, TWENTY YEARS OF HIV/AIDS IN THE WORLD: EVOLUTION OF THE EPIDEMIC AND RESPONSE IN UGANDA 2 (2001), available at http://www.aidsuganda.org/20\%20years\%20of\%20HIV.pdf [hereinafter EPIDEMIC AND RESPONSE IN UGANDA]; Uganda AIDS Comm'n, National Documentation Center (NADIC), Mandate and Background, at http://www.aidsuganda.org/uac.htm (last visited Mar. 15, 2003).

${ }_{68}$ EPIDEMIC AND RESPONSE IN UGANDA, supra note 65, at 3.

${ }^{67}$ See id.; Helen Epstein, AIDS: The Lesson of Uganda, N.Y. REv. Books, July 5, 2001 , at 18 .

${ }_{68}$ See generally EPIDEMIC AND RESPONSE IN UGANDA, supra note 65.

${ }^{69}$ Mamadou Mika Lom, Senegal's Recipe for Success, 15 AFRICA RECOVERY 24, 24 (2001), available at http://www.un.org/ecosocdev/geninfo/afrec/vol15no1/15no1pdf 
the driving force behind a declaration on AIDS made by heads of member states of the Organization of African Unity in June $1992 .{ }^{70}$ Senegal invested significant resources in the mid-1990s to increase AIDS awareness. ${ }^{71}$ In the late $1990 \mathrm{~s}$, over ninety percent of the general population in Senegal knew about HIV and methods of prevention. $^{72}$

Although both Uganda and Senegal represent success stories in the AIDS epidemic, governments rarely implement proven public health strategies due to an absence of committed political leadership and inadequate funding. Despite the epidemic's potential impact on the health and the economy of a country, many national leaders demonstrate a benign neglect of the epidemic. ${ }^{73}$ The reasons are complex. HIV/AIDS is perceived to interfere with other priorities such as national image, tourism, and even trade. ${ }^{4}$ As HIV/AIDS is associated with unlawful or stigmatized behaviors such as drug use, homosexuality, and promiscuous heterosexuality, some political leaders seek to deemphasize its prevalence in society. ${ }^{75}$ This absence of

151aid11.pdf (last visited Mar. 15, 2003).

70 Organization of African Unity, Decisions and Resolutions Adopted by the 28th Ordinary Session of the Assembly of Heads of State and Government, AHG/Res. 206 (XXVII) at 16, available at http://www.iss.co.za/AF/RegOrg/unity_to_union/pdfs/ oau/hog/2HoGAssembly1992.pdf (last visited Apr. 14, 2003).

${ }_{71}$ Nicolas Meda et al., Low and Stable HIV Infection Rates in Senegal: Natural Course of Epidemic or Evidence for Success of Prevention? 13 AIDS 1397, 1402 (1999).

72 UNAIDS, ACTING Early to PREvent AIDS: The Case of SENEGAL 17 (1999), available at http://www.unaids.org/publications/documents/ epidemiology/determinants/una99e34.pdf (last visited Apr. 14, 2003).

${ }_{73}$ J.M. Spectar, The Hybrid Horseman of the Apocalypse: The Global AIDS Pandemic and the North-South Fracas, 29 GA. J. INT'L \& COMP. L. 253, 273 (2001); Rosie DeManno, Old Warrior Mandela Brings Moral Weight to Fight Against AIDS, TORONTO STAR, July 13, 2002 at A27.

${ }_{74}$ See Audrey R. Chapman, Conceptualizing the Right to Health: A Violations Approach, 65 TENN. L. REV. 389, 402 (1998) (noting that some countries withheld statistics regarding HIV incidence to avoid discouraging tourism or stigmatizing the country's image).

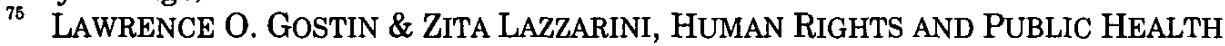
IN THE AIDS PANDEMIC 53 (1997). 
political leadership occurs irrespective of culture or region. Political inaction was as evident in the United States in the 1980s and in Kenya and Zimbabwe in the 1990s as it is in India and China today. ${ }^{76}$ The politics of AIDS are complex and dependent on resources, culture, experience, and perception. The type of health care offered by nations closely correlates with available resources. Resource-poor countries generally focus their efforts on education and basic medical treatment. More developed countries commonly offer sophisticated treatments, including antiretroviral therapy and treatment of symptoms, which stabilize the levels of HIV. ${ }^{77}$

Political leaders must have discretion to allocate resources according to the most pressing needs in a country. HIV/AIDS is not always the single greatest need. Poor countries have urgent requirements for education, transportation, sanitation, security, and other necessities. Major threats are posed to the population from violence, dislocation, and infectious diseases such as malaria and tuberculosis. Spending substantial sums of money on high technology HIV medications, for example, may not save the most lives given scarce resources. But political leaders should recognize the current or potential devastation of HIV/AIDS. There is never an excuse to ignore or underestimate the scope and impact of the pandemic. Basic AIDS education, prevention, and treatment can help produce the conditions in which people can lead healthy lives.

South African President Thabo Mbeki exemplifies the inaction of some leaders. Mbeki has questioned whether

\footnotetext{
${ }^{76}$ Maureen Dowd, Dr. Koop Defends His Crusade on AIDS, WASH. POST, Apr. 6, 1987, at B8; Susan Okie, AIDS Devouring Africa Even as Awareness Grows, WASH. PosT, Apr. 18, 1994, at A1; M. Taegtmeyer \& K. Chebet, Overcoming Challenges to the Implementation of Antiretroviral Therapy in Kenya, 2 LANCET INFECT. DIS. 51,51 (2002).

77 News Release, National Institutes of Health, New Model Suggests that AIDS Drugs May Not Abolish HIV Infection (Oct. 6, 1999), available at http://www.nih.gov/news/pr/oct99/niaid-06a.htm (last visited Mar. 15, 2003).
} 
HIV actually causes disease, stating, "[y]ou cannot attribute immune deficiency solely and exclusively to a virus." ${ }^{78}$ Such skepticism of science by a respected political leader seriously undermines AIDS education and prevention. President Mbeki has also openly doubted the accuracy of his own Department of Health estimates of the national HIV prevalence among pregnant women. The data, based on annual unlinked, anonymous HIV surveys among women attending antenatal clinics, demonstrate a thirtyfold increase in HIV prevalence-from $0.7 \%$ in 1990 to $22.4 \%$ in $1999 .^{79}$ For several years, the Ministry of Health, under President Mbeki resisted full implementation of UNAIDS guidelines for short-course antiretroviral therapy for pregnant women, ${ }^{80}$ even though it had been demonstrated to be cost effective in South Africa. ${ }^{81}$

Fortunately, there have been competing voices about the dangers of political inaction from the African National Congress. Former South African President Nelson Mandela observed: "Nothing threatens us more today than

${ }^{78}$ Mbeki: HIV Not Only Cause of AIDS, Associated PRESS, Sept. 10, 2000, at http://www.aegis.com/news/ap/2000/AP000905.html (last visited Mar. 15, 2003); South Africa and AIDS: Reason Prevails, ECONOMIST, Apr. 27, 2002, at 81 (noting that on April 24, 2002, Mr. Mbeki made his strongest statement yet that people must change their sexual behavior: "You can't be going around having hugely promiscuous sex all over the place and hope that you won't be affected.").

79 Department of Health of the Republic of South Africa, The HIV Epidemic in South Africa (Feb. 2001), at http://www.uct.ac.za/depts/mmi/jmoodie/anc0.html (last visited Mar. 15, 2003).

${ }^{80}$ See Jimmy Volmink et al., Reducing Mother-to-Child Transmission of HIV Infection in South Africa, in INFORMING JUDGMENT: CASE STUdies OF HEALTH POLICY AND RESEARCH IN SIX COUNTRIES 174, 179-81 (2001) (stating that UNAIDS has criticized laws that restrict access of antiretroviral drugs to the poor); WORLD HEALTH ORG., PREVENTION OF MOTHER-TO-ChILD TRANSMISSION OF HIV: SELECTION AND USE OF NEVIRAPINE (2001) (noting that nevirapine, an antiretroviral drug, should be on the national list of essential drugs according to Interagency Guidelines for Drug Donations of the WHO), available at http://www.who.int/docstore/hiv/PMTCT/ who_hiv_aids_2001.03.pdf 11 (last visited Mar. 15, 2003).

${ }^{81}$ Neil Söderlund et al., Prevention of Vertical Transmission of HIV: Analysis of Cost Effectiveness of Options Available in South Africa, 318 BRIT. MED. J. 1650, 1654 (1999). 
HIV/AIDS. AIDS is a scourge threatening to undo all the gains we made in our generations of struggle., ${ }^{, 2}$ More radically, the Premier of KwaZulu-Natal, the South African province most affected by HIV/AIDS, declared that he would distribute drugs to pregnant women with AIDS, in direct violation of central government policy. ${ }^{83}$ Further, the Constitutional Court of South Africa drastically altered government policy in the 2002 court case, Minister of Health and Others $v$. Treatment Action Campaign and Others (TAC), when it upheld a request by TAC to provide nevirapine, an antiretroviral drug available to the government free of charge, to pregnant mothers at public hospitals. ${ }^{84}$

\section{B. The Impact of Economic Assistance}

Even with the political will, the least developed countries still need economic assistance for HIV prevention and treatment. ${ }^{85}$ Public health strategies require resources and many countries in the South and East cannot afford the cost. $^{86}$ Countries in the North and West have not made the political and economic commitment to international aid that is necessary to reduce the global burden of the disease. ${ }^{87}$ There are compelling reasons to provide this kind of international assistance. The most fundamental reason is humanitarianism, the understanding that preventing

\footnotetext{
${ }^{82}$ Shifting Stance, Beijing Shows Drama on AIDS, N.Y. TIMES, Dec. 2, 2001, at A22.

Rachel L. Swarns, A Bold Move on AIDS in South Africa, N.Y. TIMES, Feb. 5, 2002, at A10.

${ }^{84}$ Minister of Health and Others v. Treatment Action Campaign and Others, 2002 (10) BCLR 1033 (CC) II 4 n.5, 135, available at http:/www.concourt.gov.za/ judgments/2002/tac.pdf (last visited Mar. 15, 2003).

${ }_{85}$ B. Schwartländer et al., Resource Needs for HIV/AIDS, 292 SCI. 2434, 2434 (2001).

${ }^{86}$ See id. at 2434-36.

${ }^{87}$ See Paul Blustein, Bush to Announce Three-Year AIDS Spending Initiative, WASH. POST, June 19, 2002, at A3 (noting that commitments have "fallen short" of Secretary General Kofi Annan's goal of $\$ 10$ billion a year).
} 
suffering and promoting human welfare is a reward in itself. Countries may also be motivated by their own selfinterest, because HIV/AIDS in the developing world deeply affects the health, economy, and security of people on a global scale.

In the world's least developed countries, the average annual per capita health expenditure is $\$ 16^{88}$ compared to $\$ 4600$ in the United States. ${ }^{89}$ The WHO recommends that, at a minimum, this should rise to $\$ 34 .^{90}$ Consequently, the United Nations established a general fund to fight AIDS, Tuberculosis and Malaria to promote both prevention and treatment of these diseases, ${ }^{91}$ which account for ten percent of deaths worldwide. ${ }^{92}$ Although the United Nations Secretary General Kofi Annan announced that this fund needs $\$ 7-\$ 10$ billion a year for AIDS alone ${ }^{93}$ donors pledged only $\$ 1.5$ billion in $2001^{94}$ and funding diminished further in the aftermath of the events on September 11, 2001. ${ }^{95}$ By

${ }^{88}$ U.N. CONFERENCE ON TRADE \& DEVELOPMENT, THIRD U.N. CONFERENCE ON THE LEAST DEVELOPED COUNTRIES, HOSTED BY THE EUROPEAN UNION AND THE European Parliament IN BRUSSELS, BELgIUM 17 (2001), auailable at http://www.epe.be/objective2002/2ndconference/related/program.pdf (last visited Mar. 15, 2003).

${ }_{89}$ News Release, Organisation for Economic Development, OECD Health Data 2002 (June 24, 2002) (citing health care statistics per capita in 2000), available at $\mathrm{http}: / / \mathrm{www}$.oecd.org/EN/document/0,EN-document-0-nodirectorate-no-12-31070,00. html (last visited Mar. 15, 2003).

${ }^{90}$ WORLD HEALTH ORg. COMM'N ON MACROECONOMiCS \& HEALTH, MACROECONOMICS AND HEALTH: INVESTING IN HEALTH FOR ECONOMIC DEVELOPMENT 11-12, 54, 121 (2001), available at http://www.un.org/esa/coordination /ecosoc/docs/RT.K.MacroeconomicsHealth.pdf (last visited Mar. 15, 2003).

${ }^{91}$ The Global Fund to Fight AIDS, Tuberculosis \& Malaria, Overview, at http://www.globalfundatm.org/overview.html (last visited Feb. 23, 2003).

${ }_{92}$ Anders Nordstrom, Global Fund for AIDS, Tuberculosis and Malaria, 359 LANCET 1621, 1622 (2002). See also WORLD HEAlti ORG., WORLD HEALTH REPORT 2002, at 186, available at http://www.who.int/whr/2002/whr2002_annex2.pdf (last visited Apr. 10, 2003).

${ }_{93}$ Editorial, The Global Fund Confronts AIDS, N.Y. TIMES, Dec. 13, 2001, at A38.

${ }^{94}$ Id.

95 Sarah Boseley, AIDS Bigger Problem Than Terrorism, THE GUARdian, Dec. 14,2001 , at 6 , (noting that since September 11 to date of article, "only $\$ 2,000$ has come in" for the Global Fund on HIV/AIDS), available at 
the time of the Fourteenth International AIDS Conference in Barcelona in the summer of 2002, the Fund reached only about $\$ 2.8$ billion. $^{96}$

President George W. Bush surprised many when he recently announced his Emergency Plan for AIDS Relief, in which he committed $\$ 15$ billion over the next five years, including $\$ 10$ billion in new funds, to combat the global AIDS crisis in fourteen countries in Africa and the Caribbean. ${ }^{97}$ Although the details of the plan, which have to be approved by Congress, have not been fully disclosed, $\$ 1$ billion of the additional $\$ 10$ billion is earmarked for the Global AIDS Fund ("the Fund"). ${ }^{98}$ Amplifying Bush's support for the Fund, the President also announced that Tommy Thompson, Secretary of the U.S. Department of Health and Human Services, is slated to become the chairman of the Fund. ${ }^{99}$ However, although appreciative, critics still contend that more money is necessary in order for the Fund to achieve its objectives. ${ }^{100}$ Moreover, the President's decision to earmark such a small proportion of the new funding to the Global AIDS Fund underlines the Administration's preference for unilateral solutions, which is likely to lead to less efficient use of the money. ${ }^{101}$

http://www.guardian.co.uk/aids/story/0,7369,618493,00. html (last visited Mar. 15, 2003).

${ }^{96}$ PRIYA Alagiri et al., Global Spending ON HIV/AIDS in ReSOURCE-PoOR SETTINGS 1, 4 (2002), available at http://www.kff.org/content/2002/6044/6044v2.pdf (last visited Mar. 15, 2003).

${ }^{97}$ Fact Sheet, U.S. Department of State, International Information Programs,

White House Outlines Bush HIV/AIDS Programs for Africa, Jan. 29, 2003, at http://usinfo.state.gov/regional/af/usafr/a3012901.htm (last visited Mar. 15, 2003).

${ }_{98} I d$. (noting that the remainder will be directed towards treatment and prevention programs including supplying anti-retroviral drugs for two million people).

${ }_{99}$ David Brown, U.S. Official in Line to Lead Global Fund, WASH. POST, Jan. 31, 2003 , at A2.

100 See id.

101 See Sheryl G. Stolberg \& Richard W. Stevenson, Bush AIDS Effort Surprises Many, But Advisers Call It Long Planned, N.Y. TIMES, Jan. 30, 2003, at A1 (noting that advocates "complain that the money will not be parceled out quickly enough and that areas of the world where the epidemic is exploding, including China and 
The need for donor funding is even more acute when one takes into account all health problems (beyond HIV/AIDS) in resource-poor countries. The WHO's Commission on Macroeconomics and Health estimated that to improve global health substantially, total donor funding to all low income countries would have to increase from current levels of approximately $\$ 6$ billion to $\$ 27$ billion by $2007 .{ }^{102}$ The Commission estimates that the increased funding could save eight million lives annually by $2010 .^{103}$

\section{Pharmaceuticals, InTEllectual PROPERTy, AND INTERNATIONAL TRADE}

Basic forms of HIV education, prevention, and treatment do not require sophisticated technologies. Most countries have the capacity to implement these public health strategies with little economic and technical assistance. As explained above, comprehensive prevention programs in Senegal, Uganda, and other countries have significantly reduced the prevalence of HIV or kept HIV prevalence low. ${ }^{104}$ However, more advanced treatments for HIV, such as highly active antiretroviral therapy (HAART), ${ }^{105}$ as well as future vaccines, are vital for a complete response to the epidemic. Antiretroviral therapies not only enhance the lives of individuals, but also promote the public's health. Individuals who are in antiretroviral treatment, with low viral loads, are less likely to transmit the infection to sexual or needle-sharing partners or to newborns through

India, are being ignored"); Editorial, $A$ Serious Response to AIDS, N.Y. TIMES, Feb. 1,2003 , at A18.

${ }_{102}$ WORLD HEALTH ORG. COMM'N ON MACROECONOMICS \& HEALTH, supra note 90 , at 11,92 .

${ }^{103}$ Id. at 11 .

104 STANECKI, supra note 10, at 2.

${ }_{105}$ Paul Farmer et al., Community-Based Treatment of Advanced HIV Disease: Introducing DOT-HAART (Directly Observed Therapy with Highly Active Antiretroviral Therapy), 79 BULL. WORLD HEALTH ORG. 1145, 1146 (2001) (explaining that the use of highly active antiretroviral therapy (HAART) has reduced the mortality of AIDS in North America and Europe). 
childbirth or breast feeding. ${ }^{106}$ Treatment, therefore, is clinically beneficial to individuals and a valuable component of a comprehensive HIV prevention program.

More advanced treatments for HIV, however, are highly technical and prohibitively expensive for poorer countries. Very few people living with HIV/AIDS in resource-poor settings are receiving drug therapy, such as HAART. ${ }^{107}$ Arguments against the use of HAART in resource-poor countries have been based on the high cost of medications and the lack of infrastructure necessary for using them properly. ${ }^{108}$

Should the most modern HIV treatments be available to people irrespective of the country in which they live? There is a moral argument that a child or adult in a poorer country is entitled to life-prolonging medications. If a highly effective treatment such as antiretroviral therapy is available and commonly used in developed countries, there is a valid argument that this treatment should also be accessible in less developed countries. The benefits of treatment are no less clear and the lives of people in Africa or Asia are no less important than those in North America and Europe.

The problem is that resource-poor countries cannot afford adequate health care. The difficulties are deeply rooted in a combination of household poverty, inadequate publiclysupported health care, and the high price of essential medicines. Consider the fact that the cost of wholesale combination HIV therapy in the United States ranges from $\$ 2,500$ to $\$ 8,000$ per patient per year, ${ }^{109}$ while the average

${ }^{108}$ See Mina Hosseinipour et al., Can Antiretroviral Therapy Be Used to Prevent Sexual Transmission of Human Immunodeficiency Virus Type 1? 34 CLINICAL INFECTIOUS DISEASES 1391, 1392-94 (2002).

${ }_{107}$ AIDS EPIDEMIC 2002, supra note 2, at 22-39 (noting that of 38.5 million individuals affected with HIV/AIDS in developing countries, only 230,000 individuals are receiving anti-retroviral therapy).

${ }^{108}$ Farmer, supra note 105, at 1149.

${ }^{109}$ Kenneth A. Freedberg, M.D. et al., The Cost Effectiveness of Combination 
per capita health expenditure in the least developed countries, as explained earlier, is only $\$ 16$. $^{110}$

Tragically, high infection rates are found in countries least able to cope with the financial burden of providing health care. For example, in 2002, Zimbabwe had an estimated adult HIV infection prevalence of $33.7 \%$ and an economy generating a per capita Gross National Income (GNI) of only $\$ 530 .{ }^{111}$ Mozambique's HIV adult infection rate was thirteen percent with a GNI per capita of $\$ 220 .^{112}$ By contrast, Germany had an adult infection rate of $0.10 \%$ for the equivalent period and an economy generating a per capita GNI of $\$ 25,620{ }^{113}$ Obvious consequences flow from these figures about a country's ability to provide expensive treatments for its citizens. Further, if governments are not equipped to provide modern therapies, individuals residing in these poor countries are even less able to attain these therapies. Personal wealth is very low and health insurance of any kind is scarce. ${ }^{114}$ For example, at the end of 2001, while an estimated four million South Africans were infected with HIV, only $0.25 \%$ (i.e., ten thousand) had the personal resources to pay for treatments. ${ }^{115}$

Antiretroviral Therapy for HIV Disease, 344 NEW ENG. J. MED. 824, 824 (2001).

110 U.N. CONFERENCE ON TRADE \& DEVELOPMENT, supra note 88, at 17.

111 UNAIDS/WHO WORKING GROUP ON GLOBAL HIV/AIDS \& STI SURVEILLANCE, ZIMBABWE: EPIDEMIOLOGICAL FACT SHEET ON HIV/AIDS AND SEXUALly TRANSMITTED INFECTIONS 2, 3 (2002), available at http://www.who.int/emc-hiv/ fact_sheets/pdfs/Zimbabwe_EN.pdf(last visited Mar. 15, 2003).

${ }_{11} \overline{2}$ UNAIDS/WHO WORKING GROUP ON GLOBAL HIV/AIDS \& STI SURVEILLANCE, MOZAMBIQUE: EPIDEMIOLOGICAL FACT SHEET ON HIV/AIDS AND SEXUALLY TRANSMITTED INFECTIONS 2, 3 (2002), available at http://www.who.int/emchiv/fact_sheets/pdfs/Mozambique_EN.pdf (last visited Mar. 15, 2003).

${ }_{13}$ UNAIDS/WHO WORKING GROUP ON GLOBAL HIV/AIDS \& STI SURVEILLANCE, GERMANY: EPIDEMIOLOGICAL FACT SHEET ON HIV/AIDS AND SEXUALLY TRANSMITTED INFECTIONS 2, 3 (2002), available at http://www.who.int/emchiv/fact_sheets/pdfs/Germany_EN.pdf (last visited Mar. 15, 2003).

114 OXfam, Cut the Cost Patent InJustice: How World Trade Rules Threaten THE HEALTH OF POOR PEOPLe 3 (2001), available at http://www.oxfam.org.uk/cutthecost/downloads/patent.pdf (last visited Mar. 15, 2003) [hereinafter CUT THE COST PATENT INJUSTICE].

115 Beresford, supra note 54, at 22. 
International

agencies, ${ }^{116}$

non-governmental organizations, ${ }^{117}$ and AIDS activists ${ }^{118}$ have drawn attention to the urgent need for dramatically increased availability of medications in developing countries. They have concentrated, moreover, on the high price of therapy, which is perceived as the major barrier to access. ${ }^{119}$ For example, the United Nations conducts a program of "Accelerated Access" in collaboration with five pharmaceutical companies. ${ }^{120}$ The program assists countries with implementing comprehensive packages of care, treatment, and support for their citizens living with HIV/AIDS, including advocacy for significantly reduced drug prices. ${ }^{12}$

\section{A. Patent Protection and the Artificially High Price of AIDS Medications}

Pharmaceutical companies, supported by advanced industrialized countries, often seek to maintain a high price for HIV medications. ${ }^{122}$ These largely northern-based transnational companies claim that a market price is necessary to recoup the substantial costs of research and development. ${ }^{123}$ The pharmaceutical sector argues that intellectual property protection stimulates investment and innovation. Failure to safeguard commercial interests, they

116 UNAIDS, ACCELERATING ACCESS TO HIV CARE, SUPPORT AND TREATMENT (2001), at http://www.unaids.org/acc_access (last visited Feb. 6, 2003).

${ }_{117}$ CUT THE COST PATENT INJUSTICE, supra note 114, at 3.

118 Bernard Pécoul et al., Access to Essential Drugs in Poor Countries: A Lost Battle?, 281 JAMA 361, 366-67 (1999).

119 CUT THE COST PATENT INJUSTICE, supra note 114, at 5.

${ }^{120}$ UNAIDS, ACCELERATING ACCESS TO HIV CARE, SUPPORT AND TREATMENT, supra note 116.

Id.

${ }^{122}$ OXfaM, Brazil Fights for Affordable Drugs Against HIV/AIDS, 9 PAN. AM. J. PUBLIC HEALTH 331, 335-36 (2001), available at http://www.paho.org/English/DBI/ es/v9n5-TEMA-Brazil.pdf (last visited Apr. 12, 2003) [hereinafter BRAZIL FIGHTS FOR AFFORDABLE DRUGS].

${ }^{123}$ See, e.g., Sara Fritz, It's Time to Guarantee Same Drug Prices For All, ST. Petersburg Times (Fla.), May 1, 2000, at 1A. 
suggest, would chill entrepreneurs and provide disincentives for inventors.

The international trade system is specifically designed to safeguard the proprietary interests of corporations. There are basically three levels of international trade agreements: bilateral relationships (e.g., Canada-United States Free Trade Agreement), regional agreements (e.g., North America Free Trade Agreement (NAFTA)), and multilateral arrangements (e.g., World Trade Organization/General Agreement on Tariffs and Trade (WTO/GATT)). The defense of intellectual property is embedded in each level, making it difficult for developing countries to violate patents without the imposition of trade sanctions. ${ }^{124}$

The WTO's agreement on Trade Related Intellectual Property Rights (TRIPS) establishes minimum standards for intellectual property protection, including the right to exclusively market a patented product for a minimum of twenty years. ${ }^{125}$ Northern governments use bilateral and regional trade agreements to negotiate even more stringent protection for patents under so-called "TRIPS Plus" agreements. ${ }^{126}$ By restricting the right of governments to allow the production, marketing, and import of low cost copies of patented medicines (i.e., generic drugs), international trade rules restrict competition, increase prices, and further reduce the already limited access of poor people to vital medicines. ${ }^{127}$ Patented HIV medicines typically cost between three and fifteen times as much as

124 BRAZIL FIGHTS FOR AFFORDABLE DRUGS, supra note 122, at 333.

${ }^{225}$ WORLD TRADE ORG., TRADING INTO THE FUTURE 27 (2d ed. 2001) (noting that TRIPS provides the exclusive right to market a patented product for at least 20 years), available at http://www.wto.org/english/res_e/doload_e/tif.pdf (last visited Mar. 15, 2003).

${ }^{126}$ See, e.g., Simon Barber, Stars and Stripes-To Whom are the Battle of Seattle NGOs Accountable?, BUSINESS DAY (South Africa), Jan. 20, 2000, at 2.

${ }^{127}$ See Winston P. Nagen, International Intellectual Property, Access to Health Care, and Human Rights: South Africa v. United States, 14 FLA. J. INT'L. L. 155, 162-63 (2002) (examining the extent to which international agreements limit access to essential drugs). 
their generic equivalents. ${ }^{128}$ Although there are relatively few patents for HIV medicines currently in force in Africa, ${ }^{129}$ international trade rules will militate against the availability and affordability of AIDS treatments in the future. ${ }^{130}$

The United States and other developed countries argue for the "harmonization" of intellectual property rules with the goal of conforming the patent laws of least developed countries to their own. ${ }^{131}$ Proponents argue that harmonization of strong patent laws facilitates rapid economic development of poor countries through increased trade and foreign investment. ${ }^{132}$ Indeed, Article 7 of TRIPS states that:

The protection and enforcement of intellectual property rights should contribute to the promotion of technological innovation and to the transfer and dissemination of technology, to the mutual advantage of producers and users of technological knowledge and in a manner conducive to social and economic welfare, and to a balance of rights and obligations. ${ }^{133}$

In contrast, least developed countries typically resist harmonization and perceive the process as harmful to their interests. ${ }^{134}$ As these countries often lack a scientific

\footnotetext{
${ }^{128}$ CUT THE COST PATENT INJUSTICE, supra note 114, at 4.

129 Amir Attaran \& Lee Gillespie-White, Do Patents for Antiretroviral Drugs Constrain Access to AIDS Treatment in Africa?, 286 JAMA 1886, 1887 (2001).

${ }^{130}$ CUT THE COST PATENT INJUSTICE, supra note 114, at 3-4.

131 See Kate H. Murashige, Harmonization of Patent Laws, 16 Hous. J. INT'L L. $591,597,606$ (1994).

${ }_{132}$ Keith E. Maskus, Intellectual Property Challenges for Developing Countries: An Economic Perspective, 2001 U. ILL. L. REV. 457, 457 (2001).

${ }_{133}$ Agreement on Trade-Related Aspects of Intellectual Property Rights, Apr. 15, 1994, Marrakesh Agreement Establishing the World Trade Organization, Annex 1C, in LEGAL INSTRUMENTS-RESULTS OF THE URUGUAY ROUND vol. 31, 33 I.L.M. 81, at art. 7 (1994) [hereinafter TRIPS Agreement].

${ }^{134}$ Peter Jiang, Fighting the AIDS Epidemic: China's Options Under the WTO Trips Agreement, 13 ALB. L.J. SCI. \& TECH. 223, 235 (2002).
} 
infrastructure, they are predominantly consumers of foreign technology. ${ }^{135}$ For them, enforcing foreign patents dramatically increases the cost of imported drugs and inhibits local industry. ${ }^{136}$ Moreover, lacking patents of their own, least developed countries receive few reciprocal benefits by supporting strong international patent protection.

The tension between developed and developing world perspectives is reflected in the Universal Declaration of Human Rights (UDHR). ${ }^{138}$ On the one hand, the UDHR guarantees the right to property ${ }^{139}$ and the protection of material interests resulting from scientific discovery. ${ }^{140}$ On the other hand, it guarantees the right to health, ${ }^{141}$ education ${ }^{142}$ and to share in scientific advancement and its benefits. ${ }^{143}$ Developed countries seek the right to protection of their proprietary interests resulting from scientific discovery, while least developed countries seek the right to share in scientific discoveries and to the health of the population. ${ }^{144}$

WTO rules do provide limited methods of circumventing intellectual property rules where necessary to protect the public's health. Article 31 of TRIPS provides for a

135 James Otieno-Odek, Public Domain in Patentability After the Uruguay Round: A Developing Country's Perspective with Specific Reference to Kenya, 4 TUL. J. INT'L \& COMP. L. 15, 24 (1995); Nermien Al-Ali, The Egyptian Pharmaceutical Industry After TRIPS-A Practitioner's View, 26 FORDHAM INT'L L.J. 274, 277 (2003).

136 Al-Ali, supra note 135, at 277.

${ }^{137}$ Otieno-Odek, supra note 135, at 24; Christopher J. Kay, Harmonization and Intellectual Property Human Rights in Least Developed Countries, (Dec. 21, 2001) (unpublished paper, Georgetown University Law Center, Health and Human Rights Seminar, on file with author).

${ }_{138}$ See Universal Declaration of Human Rights, G.A. Res. 217A (III), U.N. Doc. A/810, at 71 (1948), available at http://www.un.org/Overview/rights.html (last visited Mar. 15, 2003).

${ }^{139}$ Id. art. 17.

${ }_{140}$ Id. art. 27(2).

141 Id. art. 25.

142 Id. art. 26.

143 Id. art. 27(1).

144 Murashige, supra note 131, at 605. 
compulsory license, which authorizes a government to transfer patent rights to itself or a third party without the patent-holder's consent under specified circumstances. ${ }^{145}$ One of the designated circumstances is when the public interest necessitates abrogation of patent rights, for example in a national health emergency. ${ }^{146}$

Although compulsory licenses are enshrined in TRIPS, pharmaceutical companies, supported by Northern governments, have strongly resisted claims of a national health emergency, preferring to maintain their patents. For example, Thailand, under intense pressure from the United States, amended its law to provide patent protection for drugs and to limit compulsory licensing and importation of patented drugs. ${ }^{147}$ This occurred against a backdrop of an epidemic in which one million people are infected with HIV and where AIDS is the leading cause of death. ${ }^{148}$

Many of the least developed countries have a powerful argument that the AIDS pandemic has caused a national health emergency. In Kenya, nearly 700 people die from HIV disease daily, but antiretroviral treatment is out of reach for the majority of the population. ${ }^{149}$ The U.S. Census Bureau estimates that the HIV/AIDS epidemic has reduced life expectancy in South Africa by fifteen years ${ }^{150}$ and in Zimbabwe by thirty-two years. ${ }^{151}$ Compare these

\footnotetext{
145 TRIPS Agreement, supra note 133, art. 31.

${ }_{148}$ Universal Declaration of Human Rights, supra note 138, art. 31(b).

147 Rosemary Sweeney, The U.S. Push for Worldwide Patent Protection for Drugs Meets the AIDS Crisis in Thailand: A Devastating Collision, 9 PAC. RIM L. \& POL'Y J. 445-46, 449 (2000).

148 See STANECKI, supra note 10 , at 3.4.

149 Doris K. Macharia et al., Antiretroviral Therapy in the Private Sector of Nairobe, Kenya: A Review of the Experience of Five Physicians, 17 AIDS 938, 938 (2003).

${ }^{150}$ U.S. CENSUS BuREAU, HIV/AIDS SuRVEILLANCE: TRENDS AND PATTERNS OF HIV INFECTION IN SELECTED DEVELOPING COUNTRIES (2000), available at http://www.census.gov/ipc/hiv/safrica.pdf (last visited Apr. 12, 2003).

${ }_{161}$ U.S. CENSUS BUREAU, HIV/AIDS SURVEILlancE: TRENDS AND PATTERNS OF HIV INFECTION IN SELECTED DEVELOPING COUNTRIES, 2000, available at http://www.census.gov/ipc/hiv/zimbabwe.pdf (last visited Apr. 15, 2003).
} 
justifications for compulsory licenses with those made by political leaders in the United States in response to the intentional release of anthrax in 2001 even though there were only a half dozen deaths from anthrax. ${ }^{152}$ Politicians suggested that the United States exercise its compulsory licensing privilege under the TRIPS agreement to permit cheap production of the antibiotic Cipro, without the consent of Bayer Pharmaceuticals. ${ }^{153}$

There are creative ways to relax rigid trade rules to allow less developed countries to obtain essential medicines at a more affordable cost. Through the innovative thinking of political leaders in developed and less developed countries, the criteria for the issuance of compulsory licenses under Article 31 of TRIPS could be clarified. ${ }^{154}$ The international trade system should recognize the devastating public health effects of HIV/AIDS in resource-poor countries.

\section{B. Poor Countries Making AIDS Treatments Available and Affordable}

Several countries have already asserted the right to produce or purchase generic drugs at significantly reduced cost. $^{155}$ For example, low cost drugs are manufactured by Brazil, Thailand, and India. ${ }^{156}$ Generic medications can

\footnotetext{
152 James M. Hughes \& Julie L. Gerberding, Anthrax Bioterrorism: Lessons Learned and Future Directions, 8 EMERGING INFECTIOUS DISEASES 1013, 1013 (2002).

${ }^{153}$ Ed Silverman \& David Schwab, U.S. Will Respect Cipro Patent-Feds Opt Not to Allow Copies of Antibiotic, THE STAR-LEDGER (Newark, N.J.), Oct. 18, 2001, at 25 (noting that one U.S. Senator asked the White House to invoke a law that permits federal officials to both disregard a federal patent and issue a compulsory license to other companies).

${ }^{154}$ See, e.g., Thomas A. Haag, TRIPS Since Doha, How Far Will the WHO Go Toward Modifying the Terms for Compulsory Licensing?, 84 J. PAT. \& TRADEMARK OFF. SOC'Y 945 passim (2002) (discussing the possibilities to modify Article 31 of TRIPS).

${ }_{155}$ Clare Kapp, WHO Faces Funding Squeeze as Richer Countries Make a Stand, 357 LANCET 1683, 1683 (2001).

${ }^{156}$ Boseley, supra note 95.
} 
reduce the cost of a daily treatment of $\mathrm{AZT}, 3 \mathrm{TC}$ and nevirapine from $\$ 3.20$ to $\$ 1.55 .^{157}$ After conducting research trials to determine the safety and efficacy of imported generic HIV/AIDS drugs, ${ }^{158}$ countries such as Nigeria have decided to begin importing them. ${ }^{159}$ The actions of these states are driven by a need and desire to provide for their citizens. ${ }^{160}$

These actions, however, have been contested. The United States has attempted to use the WTO to force conformity with international patent law. It began, although later dropped, proceedings against Brazil for production of generic HIV/AIDS drugs. ${ }^{161}$ In 2001, a conglomerate of forty-one major drug companies sued the South African government in the South African courts to block the 1997 Medicines Act, on the grounds that it was a breach of international patent protection. ${ }^{162}$ Following intense international pressure, culminating in a petition to "Drop the Case" signed by 260,000 people and 140 organizations in 130 countries, the companies withdrew the lawsuit. ${ }^{163}$

${ }^{157}$ S. Africa-AIDS-Drugs: AIDS Activists Defy Law by Bring Anti-AIDS Drugs into S. Africa, Jan. 29, 2002, (noting that generic versions of antiretroviral drugs would reduce the daily cost of treatment by one half: $\$ 3.20$ to $\$ 1.55$ ), at http://www.aegis.com/news/afp/2002/AF020150.html (last visited Mar. 31, 2003).

${ }^{158}$ Nigeria Buying Generic Drugs for an AIDS Treatment Trial, N.Y. TIMES, Nov. 30,2001 , at A12.

${ }_{159}$ Chris McGreal, Defiant Nigeria to Import Cheap Copies of HIV Drugs, THE GUARDIAN, Dec. 11, 2001, at 2, available at www.guardian.co.uk/aids/story/ $0,7369,616827,00 . h t m l$ (last visited Mar. 15, 2003).

${ }^{160}$ GLOBAL MANIFESTO, DURBAN SOUTH AFRICA (2000) (proclaiming "We are united with a single purpose, to ensure that everyone with HIV and AIDS has access to fundamental rights of healthcare and access to life-sustaining medicines. AIDS has become a catastrophe that threatens the very future of this planet."), available at http://www.actupny.org/reports/durban-access.html (last visited Mar. 15, 2003).

${ }_{161}$ US Drops Brazil AIDS Drugs Case, BBC NEWS, June 25, 2001, available at http://news.bbc.co.uk/2/hi/english/business/newsid_1407000/1407472.stm (last visited Mar. 27, 2003).

${ }^{162}$ See, e.g., Carla Power et al., Paying for AIDS, NEwSwEEK INT'L, Mar. 19, 2001, at 16-17.

${ }^{163}$ Press Release, Medecins Sans Frontieres, Drug Companies in South Africa Capitulate Under Barrage of Public Pressure (Apr. 19, 2001), available at http://www.lists.doctorswithoutborders.org/pr/2001/04-19-2001.shtml (last visited 
Surprisingly, despite the consistently negative response of the United States and multinational companies, international law experts have supported the right of least developed countries to circumvent patent rights to safeguard the public's health. ${ }^{164}$ The decision to drop the litigation in South Africa was also greeted by positive responses from bodies as diverse as Doctors without Borders, ${ }^{165}$ UNAIDS,${ }^{166}$ and the WTO itself, whose DirectorGeneral, Mike Moore, felt that the settlement proved that "WTO Agreements, such as TRIPS, contain the necessary flexibility to meet the health needs of developing countries." 167

The HIV/AIDS pandemic has turned the patent question into an explosive issue, forcing the WTO to resolve the problem. In November 2001, in Doha, Qatar, the Ministerial Conference of WTO declared that TRIPS should be interpreted to support public health and allow for patents to be overridden if required to respond to emergencies such as the AIDS epidemic. ${ }^{168}$ While a major achievement, the declaration ignored one significant problem. Countries with little or no manufacturing capability must import drugs. The Doha rules allowed them to break patents to import, but did not authorize countries to override patents for the purposes of export to countries in need. ${ }^{169}$ In December 2002 in Geneva, although

Mar. 15, 2003).

${ }_{164}$ Michael Halewood, Regulating Patent Holders: Local Working Requirements and Compulsory Licenses at International Law, 35 OSGOODE HALL L.J. 243 passim (1997).

${ }_{165}$ Medecins Sans Frontieres, supra note 163.

166 Press Release, UNAIDS, UNAIDS Welcomes Outcome of South African Court Case (Apr. 19, 2001), available at http://www.unaids.org/whatsnew/press/eng/pressa rc01/SAfrica_190401.htm (last visited Mar. 15, 2003).

${ }_{167}$ Mike Moore, Moore Welcomes News of Settlement of South Africa Drug Lawsuit, (Apr. 19, 2001), available at http://www.wto.org/english/news_e/spmm_e/ spmm58_e.htm (last visited Mar. 15, 2003).

${ }_{168}$ Declaration on the TRIPS Agreement and Public Health, Nov. 14, 2001, Ministerial Conference, 4th Session, para. 4, WT/MIN(01)/DEC/2 (2001) [hereinafter Declaration on the TRIPS Agreement].

169 Haag, supra note 154, at 947, 951-52; Declaration on the TRIPS Agreement, 
143 of the WTO's 144 members agreed on a solution, the lone holdout, the United States, obstructed the agreement. ${ }^{170}$ American negotiators lobbied to limit covered medicines to those for HIV/AIDS, malaria, tuberculosis, and a few diseases that affect primarily Africa. ${ }^{171}$ Other countries wanted a more flexible approach on access to medicines that allows nations to protect public health as they see fit. ${ }^{172}$ As a result, no agreement was reached by the time that the talks ended. After the debacle in Geneva, the Bush administration pledged not to bring trade pressure against countries that export cheap drugs for HIV/AIDS and other resource-poor country epidemic diseases. ${ }^{173}$

\section{Non-Price Barriers to Treatment Access: Infrastructure and National Priorities}

Much of the discourse on barriers to access to HIV treatments has concentrated on the issue of price. However, price is not the only barrier, and it is probably not even the most difficult one to overcome. The problems of fair and efficient methods of dissemination to people in need remain. ${ }^{174}$ Allocation and distribution of drugs within crowded cities, among homeless people, and in remote villages requires organized transportation and communication systems. The health care system may not be capable of accurately diagnosing HIV, monitoring viral load, and checking for adverse reactions. Patients must

\footnotetext{
supra note 168 , para. 4.

${ }_{170}$ Jeffrey Sparshott, U.S. Refusal Thwarts WTO Drug-Patent Talks, WASH.

PosT, Dec. 25, 2002, at C10.

17 Haag, supra note 154, at 955.

${ }^{172}$ Id. at 947, 956-59.

173 Michael M. Phillips, U.S. Eases Drug-Patent Rules, WALL ST. J., Dec. 23, 2002, at $\mathrm{A} 4$.

174 See Bureau of OcEans \& InT'L ENVTl. \& ScI. AFF., U.S. DeP'T OF ST., 1999 U.S. INTERNATIONAL RESPONSE TO HIV/AIDS (1999) (noting a "sophisticated health provider and laboratory infrastructures" are also necessary to treat persons with HIV in developing countries successfully), at http://www.state.gov/www/global/oes/ health/1999_hivaids_rpt/agency_strats.html (last visited Mar. 15, 2003).
} 
also be educated correctly about the strict regimen of taking medication.

Taken together, these problems mean that, even if distribution can be achieved, the drug may not be prescribed or taken appropriately. Incorrect or intermittent use of antiretroviral medications would create serious health risks for individual patients and pose a wider risk to the population; public health agencies are concerned that the virus could become resistant to existing medicines, rendering them less effective. The problems of resistance to antiretroviral medication already exist. ${ }^{175}$ They would be exacerbated by large scale distribution to patients who do not have the health care and support systems needed to ensure appropriate use. These concerns are legitimate and often on the minds of Northern states and aid donors.

However, care must be taken as they touch on sensitive issues. The public health community must reexamine the issue of HIV/AIDS medications in poor countries in the setting of rising mortality, falling drug prices, and innovative methods of drug delivery. Reacting to a comment by U.S. Agency for International Development Director Andrew Natsios, who indicated that Africans could not handle antiretroviral drugs because they had no concept of time, the Zimbabwe Health Minister, Timothy Stamps, said: "Though we do not have clocks and roads in Africa we do know the time and time is ticking away inexorably for some of our states."176 In response to legitimate demands, researchers are developing cheap, simple, and effective alternative treatments and monitoring technologies to improve the medical management of patients on

175 Dirk Albrecht et al., Reappearance of HIV Multidrug-Resistance in Plasma and Circulating Lymphocytes after Reintroduction of Antiretroviral Therapy, $24 \mathrm{~J}$. CLINICAL VIROLOGY 93 passim (2002).

${ }^{176}$ Brian Conway et al., Development of Drug Resistance in Patients Receiving Combinations of Zidovudine, Didanosine, and Nevirapine, 15 AIDS 1269 passim (2001). 
antiretroviral therapy. ${ }^{177}$ For instance, in Haiti, researchers successfully used a directly observed therapy (DOT) program to monitor HAART (DOT-HAART) in HIV patients. ${ }^{178}$

Making expensive HIV medications widely available would also raise questions of equity and cost-effectiveness. No one doubts that the appropriate use of these drugs would provide substantial benefits to patients and their communities. But some may ask why persons living with HIV/AIDS should receive special consideration. Many endemic diseases in developing countries could be prevented or treated with vaccines or pharmaceuticals that are not accessible to the population, including simple interventions such as penicillin and oral rehydration. For example, isoniazid and co-trimoxazloe prophylaxis against tuberculosis $^{179}$ and pneumonia respectively are highly effective but rarely available to poor people in less developed countries. ${ }^{180}$ Similarly, almost eighteen million people, mostly in Africa and Central or South America, are infected with onchocerciasis (river blindness) which is curable by administering a single oral dose of Ivermectin (trade name: Mectizan) per year. ${ }^{181}$ Interventions for these and many other diseases may be more cost effective, and entail less risk than for the most expensive HIV therapies. Similarly, if the extensive resources needed to purchase,

\footnotetext{
${ }^{177}$ Joan Stephenson, Cheaper HIV Drugs for Poor Nations Bring a New Challenge: Monitoring Treatment, 288 JAMA 151,151 (2002); Paul J. Weidle et al., HIVIAIDS Treatment and HIV Vaccines for Africa, 359 LANCET 2261, 2261 (2002).

${ }_{178}$ Farmer, supra note 105, at 1147.

179 Rajesh Gupta et al., Responding to Market Failures in Tuberculosis Control, 293 SCI. 1049, 1049 (2001).

${ }_{180}$ Karen Zwi et al., Cheaper Antiretrovirals to Treat AIDS in South Africa: They Are At Their Most Cost Effective in Preventing Mother to Child Transmission, 320 BRIT. MED. J. 1551, 1551 (2000).

${ }^{281}$ The Carter Center, River Blindness Program (stating that in response to the widespread onchocerciasis infections, the manufacturer of Mectizan has "donated the drug treatments to the world for as long as there is a need"), available at http://www.cartercenter.org/healthprograms/showdoc.asp?programID=2\&submenu= healthprograms (last visited Mar. 26, 2003).
} 
distribute, and monitor HIV drugs were used for other pressing needs such as food, sanitation and primary health care, lives might be saved at a lower cost. For example, the percent of children in sub-Saharan countries who are malnourished has steadily increased since $1970,{ }^{182}$ thirtyeight percent of inhabitants do not have access to safe water, ${ }^{183}$ and the lifetime risk of maternal death due to inadequate family planning and health care can be as high as one in nine. ${ }^{184}$

These difficult problems of resource allocation are endemic in the developing world and in the response to HIV/AIDS specifically. They have been a recurring theme of this Article and raise several important questions. What are the best uses for scarce public health and health care resources? Should significant funding be devoted for, say, high cost antiretroviral treatment or for more basic health services, including antenatal care, primary health care, and tuberculosis and Sexually Transmitted Diseases (STD) treatment? Should intellectual property be protected to spur investment and innovation or should patents be relaxed to ensure access to life-saving medications in the least developed countries?

There are no easy answers to these and other dilemmas, but one thing is clear. The most developed countries of the North and West have failed utterly to see the critical need for sharing resources with the South and East. These highly industrialized countries may have articulated the humanitarian arguments that lie at the heart of international aid, but they have provided only a small fraction of the resources necessary to implement them.

${ }^{182}$ Per Pinstrup-Andersen, Nutrition and Development, INT'L FOOD POL'Y RES. INST. 1 (Nov. 2000).

${ }_{183}$ UNITED NATIONS CHILDREN'S FUND, GLOBAL WATER SUPPLY AND SANITATION SECTOR REPORT 41 (2000), available at http://www.unicef.org/programme/wes/ pubs/global/global.htm (last visited Mar. 24, 2003).

${ }_{184}$ Carolyn Lay, Family Planning Access is Seen as Key Determinant in Maternal Well Being, 22 POPLINE 3 (2000), available at http://population.newc.com/teampu blish/uploads/May-June_2000_Issue.pdf (last visited Apr. 12, 2003). 
This is not only a tragedy for resource-poor countries, but will affect the health, economy, and security of people everywhere.

\section{THE ETHICS OF HUMAN SUBJECT RESEARCH}

Global success in combating HIV/AIDS must be measured by its impact on our children and young people. Are they getting the information they need to protect themselves from HIV? Are girls being empowered to take charge of their sexuality? Are infants safe from the disease, and are children orphaned by AIDS being raised in loving, supportive environments? These are the hard questions we need to be asking. These are the yardsticks for measuring our leaders. We cannot let another generation be devastated by AIDS.

Carol Bellamy, Executive Director, UNICEF (2002).

\section{A. Reduction of Perinatal Transmission in Resource-Poor Countries}

Vertical transmission of HIV from mother to child occurs intrauterine (i.e., inside the uterus), intrapartum (i.e., during labor and delivery), and postpartum during breastfeeding. ${ }^{185}$ UNAIDS and WHO estimate that of the over two million HIV-infected women giving birth each year, approximately 600,000 , or thirty percent, transmit the infection to their children. ${ }^{186}$ With over ninety percent of

\footnotetext{
${ }^{185}$ Beth R. Santmyire, Vertical Transmission of HIV from Mother to Child in SubSaharan Africa: Modes of Transmission and Methods for Prevention, 56 OBSTETRICAL \& GYNECOLOGICAL SURV. 306, 306 (2001).

186 M. Berer, Reducing Perinatal HIV Transmission in Developing Countries Through Antenatal and Delivery Care, and Breastfeeding: Supporting Infant Survival by Supporting Women's Survival, 77 BULl. WORLD HEALTH ORG. 871, 871
} 
the world's HIV-infected children living in sub-Saharan Africa, the rate of HIV infection among women attending antenatal clinics in this region ranges from ten to fifty percent. ${ }^{187}$ Studies suggest that in Africa, approximately sixty-five thru seventy percent of HIV transmission occurs intrapartum, nineteen thru twenty-three percent intrauterine, and eleven through twelve percent postpartum. In the absence of intervention, vertical transmission is estimated to be fourteen through twentyfive percent in developed countries and twenty-one through forty-three percent in less developed countries; ${ }^{188}$ the difference in rates of transmission are due mostly to breast feeding in less developed countries.

The administration of antiretroviral agents to mother and child around the time of birth may be the most effective means of an intervention to reduce vertical transmission although substitution of formula feeding for breast feeding, and caesarean section are viable alternatives. Numerous international observational studies have reported significant reductions in vertical transmission with treatment. ${ }^{189}$. In 1994, the AIDS Clinical Trial Group Study 076 ("ACTG 076") showed a two-thirds reduction in transmission from HIV-infected women who received a complex regimen of zidovudine, an antiretroviral agent, for themselves and their infants. ${ }^{190}$ Impressive decreases in vertical HIV transmission have been achieved in North

(1999); Chewe Luo, Strategies for Prevention of Mother-to-Child Transmission of $H I V, 8$ REPROD. HEALTH MATTERS 144, 144 (2000).

${ }_{187}$ UNAIDS, AIDS in Africa, at http://www.unaids.org/publications/documents/ epidemiology/determinants/saepap98.html (last visited Mar. 24, 2003).

${ }_{188}$ Francois Dabis et al., Rates of Mother-to-Child Transmission of HIV-1 in Africa, America and Europe: Results from 13 Perinatal Studies, 8 (5) J. ACQUIRED IMMUNODEFICIENCY SYNDROME \& HUMAN RETROVIROLOGY 506, 508 (1995).

${ }_{169}$ Kevin M. De Cock et al., Prevention of Mother-to-Child HIV Transmission in Resource-Poor Countries: Translating Research into Policy and Practice, 283 JAMA 1175,1175 (2000).

${ }_{190}$ Edward M. Connor et al., Reduction of Maternal-Infant Transmission of Human Immunodeficiency Virus Type 1 with Zidovudine Treatment, 331 NEW ENG. J. MED. 1173, 1173 (1994). 
America and Europe based on these clinical trials. ${ }^{191}$ While formula feeding can reduce the risk of HIV transmission, it creates other risks because breast-feeding has nutritional, immunological, and birth spacing benefits that deserve preservation if possible. ${ }^{192}$ In addition, formula feeding requires access to nutritionally sound formulas and potable water, which may be scarce in some regions. Caesarean section also reduces vertical transmission, although its cost effectiveness is not established and it is not feasible in areas with few resources. ${ }^{193}$

The success in reducing vertical transmission in industrialized countries through antiretroviral therapy stands in stark contrast to the continuing perinatal HIV epidemic in less developed countries. ${ }^{194}$ In low-resource settings, where infants of infected mothers are continuously exposed to HIV, the cost of the regimen used in ACTG 076 is too expensive and complex. The estimated cost of the regimen is $\$ 200$ (with discounts in pricing to less developed countries), which makes the treatment unavailable to most people in sub-Saharan Africa where the annual health expenditure per person is between $\$ 2$ and $\$ 40 .{ }^{195}$ Additional barriers include the difficulty in compliance with a regimen entailing administration of a drug four or five times daily for weeks, limited infrastructure for distributing drugs and monitoring compliance, and inadequate maternal-child health care services.

\footnotetext{
191 Mary Lou Lindegren et al., Trends in Perinatal Transmission of HIV/AIDS in the United States, 282 JAMA 531 passim (1999).

192 Angus Nicoll et al., Infant Feeding Policy and Practice in the Presence of HIV-1 Infection, 9 AIDS 107, 107 (1995).

${ }_{193}$ Elective Caesarean-Section Versus Vaginal Delivery in Prevention of Vertical HIV-1 Transmission: A Randomised Clinical Trial, 353 LANCET 1035, 1035 (1999).

${ }_{194}$ Lynne M. Mofesnson \& James A. McIntyre, Advances and Research Directions in the Prevention of Mother-to-Child HIV-1 Transmission, 355 LANCET 2237, 2237 (2000).

${ }_{195}$ Elliot Marseille et al., Cost Effectiveness of Single-Dose Nevirapine Regimen for Mothers and Babies to Decrease Vertical HIV-1 Transmission in Sub-Saharan Africa, 354 LANCET 803, 803 (1999).
} 
Research in sub-Saharan Africa and Southeast Asia has demonstrated that less expensive short-course antiretroviral regimens diminish perinatal transmission by one-third to one-half. ${ }^{196}$ A trial in Uganda of a single oral dose of nevirapine, an antiretroviral drug, given to the mother and newborn had similar benefits. ${ }^{197}$ These results applied to women who did, ${ }^{198}$ and did not, ${ }^{199}$ breast-feed, although the formula-fed groups had even greater reductions in transmission. Economic analyses have suggested that short-course therapies can achieve significant health and financial benefits considering the cost of the therapy. ${ }^{200}$ As a result, WHO and UNAIDS recommend short-course perinatal antiretroviral therapy and advise HIV-infected women not to breast-feed their infants where this can be accomplished safely. ${ }^{201}$

Despite the clinical research, economic analysis, and public health guidance, few developing countries (with the exception, for example, of Botswana, Thailand, and Brazil) have national policies for integration of preventive

196 François Dabis et al., 6-Month Efficacy, Tolerance, and Acceptability of a Short Regimen of Oral Zidovudine to Reduce Vertical Transmission of HIV in Breastfed Children in Côte d'Ivoire and Burkina Faso: A Double-Blind Placebo-Controlled Multicentre Trial, 353 LANCET 786, 786 (1999); Stefan Z. Wiktor et al., Short-Course Oral Zidouudine for Prevention of Mother-to-Child Transmission of HIV-1 in Abidjan, Côte d'Ivoire: A Randomised Trial, 353 LANCET 781, 781 (1999); Nathan Shaffer et al., Short-Course Zidovudine for Perinatal Transmission in Bangkok, Thailand: A Randomised Controlled Trial, 353 LANCET 773, 773 (1999).

${ }_{197}$ Laura A. Guay et al., Intrapartum and Neonatal Single-Dose Nevirapine Compared with Zidovudine for Prevention of Mother-to-Child Transmission of HIV-1 in Kampala, Uganda: HIVNET 012 Randomised Trial, 354 LANCET 795, 795 (1999).

198 Id.

199 CEnTERS FOR DISEASE CONTROL \& PREVENTION, Administration of Zidovudine During Late Pregnancy and Delivery to Prevent Perinatal HIV Transmission-Thailand 1996-1998, 47 MORBIDITY \& MORTALITY WKLY. REP. 151, 151 (1998).

200 Söderlund, supra note 81 passim.

201 UNICEF, UNAIDS, \& WORLD HEALTH ORG., HIV AND INFANT FEEDING: GUIDELINES FOR DECISION-MAKERS (1998), available at http://www.unaids.org/ publications/documents/mtct/infantpolicy.html (last visited Mar. 25, 2003); Berer, supra note 186 , at $871-75$. 
antiretroviral therapy in antenatal clinics. ${ }^{202}$ As discussed below, those resisting these kinds of interventions object on grounds of economics ${ }^{203}$ and ethics. ${ }^{204}$ Neither the economic nor the ethical arguments are convincing. In fact, citizens and advocacy groups have powerfully influenced government policy, as exemplified by the successful suit by the Treatment Action Campaign (TAC) in South Africa as previously discussed. ${ }^{205}$

Economic objections understandably rest on the still relatively high cost of short course therapies when compared to meager health budgets, and on the need to have a reasonably well-functioning health care system. There are also arguments based on distributive justice, for example, why HIV should hold a special status. But prevention of perinatal transmission, which can be achieved sometimes with a single dose, will save countless lives of young people with productive futures. The economic benefits of preventing perinatal transmission cannot be compared with treatment once the disease has taken hold, which requires far more expensive, complex, and arduous treatment regimes over the course of a lifetime.

The ethical objections to short-course therapy rest primarily on the need for voluntary counseling and testing before administration of antiretroviral drugs. Some believe that poor, uneducated women cannot give fully informed and voluntary consent to testing and treatment. However, informing women in ways that are culturally and

\footnotetext{
202 Luo, supra note 186 , at 144.

203 David Wilkinson et al., Short Course Antiretroviral Regimens to Reduce Maternal Transmission of HIV: May be Effective but Shouldn't be Allowed to Strangle Research that Might Help Africans, 318 BRIT. MED. J. 479 passim (1999).

${ }^{204}$ Catherine Hankins, Preventing Mother-to-Child Transmission of HIV in Developing Countries: Recent Developments and Ethical Implications, 8 REPROD. HEALTH MATTERS 87 passim (2000).

${ }^{205}$ Chris McGreal, Court Orders Mbeki to Provide AIDS Drug, ThE GuARdian, Dec. 15, 2001, at http://www.guardian.co.uk/aids/story/0,7369,619153,00. html (last visited Mar. 20, 2003); South Africa to Provide AIDS Drug, BBC NEwS, Apr. 4, 2002, at A1.
} 
linguistically appropriate can ensure voluntary and informed consent. ${ }^{206}$ Another alternative is to offer routinely a single dose of nevirapine orally to the mother and to the infant without the need for an HIV test. Given the devastation of the perinatal HIV epidemic and the availability of uncomplicated, inexpensive interventions, it ought to be possible to relieve the suffering and loss of life in developing countries.

Women and children, wherever they live, deserve a comprehensive package of care in pregnancy, during delivery, and after birth. UNAIDS, UNICEF, and WHO recommend: early access to perinatal care, voluntary and confidential counseling and HIV testing for women and their partners, antiretroviral preventative therapy, care during labor and delivery, and counseling on alternative methods of infant feeding including support for those who choose breast-feeding replacements. ${ }^{207}$ Additionally, women deserve access to methods of family planning, children deserve post-natal care, and families deserve nutritional and social support. ${ }^{208}$

\section{B. The Controversy Over Research Ethics in International Collaborative Research}

It is clear that short-course antiretroviral therapy can have enormous benefits for less developed countries. But this utilitarian argument has been challenged as an insufficient justification for conducting research trials in Africa, Asia, and the Caribbean to determine the efficacy of a low-dose regimen of zidovudine (AZT) in pregnant

\footnotetext{
${ }^{206}$ Carel B. Ijsselmuiden \& Ruth Faden, Research and Informed Consent in Africa-Another Look, 326 NEW ENG. J. MED. 830, 833 (1992).

${ }^{207}$ Berer, supra note 186, at 871.

${ }^{208}$ Luo, supra note 186, at 144; Rachel Baggaley \& Eric van Praag, Antiretroviral Interventions to Reduce Mother-to-Child Transmission of Human Immunodeficiency Virus: Challenges for Health Systems, Communities and Society, 78 BULL. WORLD HEALTH ORG. 1036, 1036 (2000).
} 
women. $^{209}$ Fifteen placebo-controlled trials (PCTs) ${ }^{210}$ were conducted in the mid-to-late 1990s in developing countries. ${ }^{211}$ A trial conducted in Thailand was an equivalency trial in which a regimen that has already been proven effective (the ACTG 076 regimen) was compared with a second regimen (low dose antiretrovirals) to determine if it is as effective, but less toxic or expensive. ${ }^{212}$ Most of the studies were funded by the National Institutes of Health (NIH) and the Centers for Disease Control and Prevention (CDC), while the others were funded by European countries, South Africa, and UNAIDS. ${ }^{213}$

There is no doubt that if these PCTs had been conducted in the United States they would have been regarded as unethical. No trial would be ethically approved in a developed country if it denied access to an intervention thought to hold promise of being at least as effective as, if not more effective than, the prevailing standard of care. The question posed is whether it is ethical to withhold a treatment in a poor country, when the treatment is used as the standard of care in developed countries but is not attainable in the country in which the research is taking place. ${ }^{214}$ The issue is not whether it is ethical for First World researchers to investigate a therapy that would be out-of-reach or unimportant in the country in which the

${ }^{209}$ Zulfiqar A. Bhutta, Ethics in International Health Research: A Perspective from the Developing World, 80 BULL. WORLD HEALTH ORG. 114, 115 (2002), available at http://www.who.int/bulletin/pdf/2002/bul-2-E-2002/80(2)114-120.pdf (last visited Apr. 10, 2003).

${ }_{210}$ In a placebo controlled trial, one group of persons is given the experimental treatment, and one group (the control group) is given a placebo, such as a sugar pill. The incidence of transmission in the two groups is compared to determine whether the experimental treatment had any effect.

${ }_{211}$ Bhutta, supra note 209, at 115; Ronald Bayer, Ethical Challenges of HIV Vaccine Trials in Less Developed Nations: Conflict and Consensus in the International Arena, 14 AIDS 1051, 1054 (2000).

212 Bayer, supra note 211, at 1054.

213 Ronald Bayer, The Debate Over Maternal-Fetal HIV Transmission Prevention Trials in Africa, Asia, and the Caribbean: Racist Exploitation or Exploitation of Racism?, 88 AM. J. PUB. HEALTH 567, 567 (1998).

${ }^{214}$ Id. 
research takes place (e.g., testing high technology interventions for cancer in the least developed countries). International collaborative research that is of little benefit to the host country arguably is unethical, but the shortcourse protocols were deliberately designed to find affordable treatments in developing countries. ${ }^{215}$

The short-course studies provoked a storm of controversy. ${ }^{216}$ Critics argued that placebo controls were never justified when an effective treatment exists; subjects in the control group must receive the "best known treatment," meaning the highest standard that would be available in developed countries. ${ }^{217}$ Critics argued that high levels of care for research subjects were mandated by the Helsinki Declaration which was revised in 2000: "A new method should be tested against... the best current prophylactic, diagnostic, and therapeutic methods. This does not exclude the use of placebo, or no treatment, in studies where no proven prophylactic, diagnostic or therapeutic method exists." ${ }^{218}$ Critics also cited the Council of International Organizations of Medical Societies' (CIOMS) Guidelines on Biomedical Research, which state that ethical and scientific review should be conducted according to the standards of the sponsoring agency and should be "no less exacting" than if conducted in the sponsoring country. ${ }^{219}$ In draft revisions to the guidelines, CIOMS states that the Helsinki standard should be adopted unless there are sound reasons to use a control, such as

${ }^{215}$ Harold Varmus \& David Satcher, Ethical Complexities of Conducting Research in Developing Countries, 337 NEW ENG. J. MED. 1003, 1004 (1997).

${ }_{216}$ Peter Lurie \& Sidney M. Wolf, Unethical Trials of Interventions to Reduce Perinatal Transmission of the Human Immunodeficiency Virus in Developing Countries, 337 NEW ENG. J. MED. 853, 853-54 (1997).

${ }_{217}$ Marcia Angell, The Ethics of Clinical Research in the Third World, 337 NEW ENG. J. MED. 847, 848 (1997).

${ }^{218}$ World MEd. Ass'N DeClaration of Helsinki, EthiCAl PRINCIPLES for MEDICAL RESEARCH INVOLVING HUMAN SUBJECTS (2000), available at http://www.wma.net/e/policy/17-c_e.html (last visited Mar. 25, 2003).

${ }^{219}$ Council for Int'l Org. of Medical Sciences, International Guidelines for Ethical Review of Epidemiological Studies, 19 L. MED. \& HEALTH CARE 191, 191 (1991). 
when withholding the best current treatment would result in no serious adverse effect and a comparative study of two treatments would yield no reliable scientific results. ${ }^{220}$ Other scholars have elaborated on the ethical conditions that would justify use of PCTs in cases where there is a proven treatment. ${ }^{221}$

Marcia Angell, then editor of the New England Journal of Medicine, harshly compared the short-course trials to the infamous study in Tuskegee, Alabama where African American men with syphilis were simply observed and left untreated:

Women in the Third World would not receive antiretroviral treatment anyway, so the investigators are simply observing what would happen to the subjects' infants if there were no study. And a placebo-controlled study is the fastest, most efficient way to obtain unambiguous information that will be of greatest value in the Third World. ${ }^{22}$

Angell criticized this logic: "All the rationalizations boil down to asserting that the end justifies the means-which it no more does in Africa than it did in Alabama." ${ }^{223}$

Harold Varmus and David Satcher, then heads of NIH and CDC respectively, responded vigorously:

[Critics] allude inappropriately to the infamous Tuskegee study, which did not test an intervention.

220 Patricia Huston \& Robert Peterson, Withholding Proven Treatment in Clinical Research, 345 NEW ENG. J. MED. 912, 912 (2001).

${ }^{221}$ Ezekiel J. Emanuel \& Franklin G. Miller, The Ethics of Placebo-Controlled Trials-A Middle Ground, 345 NEW ENG. J. MED. 915, 915 (2001); Benjamin Freedman et al., Placebo Orthodoxy in Clinical Research II: Ethical, Legal, and Regulatory Myths, 24 J. LAW, MED., \& ETHICS 252, 252 (1996); Benjamin Freedman et al., Placebo Orthodoxy in Clinical Research I: Empirical and Methodological Myths, 24 J. LAW MED. \& ETHICS 243, 243 (1996).

Angell, supra note 217, at 848 .

${ }^{223}$ Marcia Angell, Tuskegee Revisited, WALL ST. J., Oct. 28, 1997, at A22. 
The Tuskegee study ultimately deprived people of a known, effective, affordable intervention. To claim that countries seeking help in stemming the tide of maternal-infant HIV transmission by seeking usable interventions have followed that path trivializes the suffering of the men in the Tuskegee study and shows a serious lack of understanding of today's trials.

Varmus and Satcher, supported by a broad array of AIDS researchers in developed ${ }^{225}$ and less developed ${ }^{226}$ countries, strongly defended the trials on the grounds that PCTs were scientifically necessary; an equivalency study between two interventions of unknown benefit would not make clear whether either intervention was more effective than no intervention. There were also confounding factors such as the relative toxicity of the interventions. Further, they argued that an ACTG 076 regimen group would be of little use since the regimen is unaffordable and unavailable in the host country.

As Ronald Bayer suggests, this was not a clash over first principles, but a dispute over the application of agreed-upon principles in different social conditions. ${ }^{227}$ The established ethical principle is that human research subjects should not be denied the standard of care, but which standard-the prevalent standard achievable in the most advanced industrialized economy or the standard in the host country? In this context, policymakers had to make treatment decisions under conditions of poverty, scarcity, and urgent need. Everyone felt conflicted making these critical choices and would have liked to have had a uniform standard everywhere. The research subjects were informed,

\footnotetext{
224 Varmus \& Satcher, supra note 215, at 1004.

225 Michael H. Merson, Letter to the Editor, 338 NEw ENG. J. MED. 836, 836 (1998); Donald Francis, Letter to the Editor, 338 NEw ENG. J. MED. 837, 837 (1998).

${ }^{226}$ Salim S. Abdool Karim, Placebo Controls in HIV Perinatal Transmission Trials: A South African's Viewpoint, 88 AM. J. PUB. HEALTH 564, 564 (1998); Edward K. Mbidde, Letter to the Editor, 338 NEW ENG. J. MED. 837, 837 (1998).

${ }_{227}$ Bayer, supra note 213, at 567.
} 
consented, and not exposed to risk; the study was designed to benefit host countries, which desired the research and ethically approved the protocol; and the results may vastly improve the lives of the world's poorest and most disadvantaged mothers and children. Given the social and economic context, it may have been unethical not to conduct the most rigorous and efficient international studies to prevent perinatal transmission in the least developed countries. $^{228}$

\section{CONCLUSION}

Secretary General Kofi Annan [has] asked for seven billion dollars a year for a global fund to fight infectious diseases. I tell you, I've done a lot of work in this area. We can turn this epidemic around in three years. Brazil cut the death rate in half in three years with medicine and prevention. Uganda, with no medicine, cut the death rate in half in five years. We do not have to have 100 million AIDS cases in five years. We do not have to let countries be consumed by this. I promise you, fledgling democracies will be destroyed by this. They will not be able to sustain an AIDS caseload of 100 million. And we don't have to have it happen. We ought to fund this program. It's not very much money.

\section{William Jefferson Clinton, Former President of the} United States (2001).

The world is in the midst of one of the great pandemics in human history with untold suffering, illness, and death. The devastating social and economic effects are just as sobering as the health effects. One would expect the

\footnotetext{
${ }^{228}$ Catherine M. Wilfert et al., Perinatal HIV Intervention Research in Developing Countries Workshop Participants, Science, Ethics, and the Future of Research into Maternal Infant Transmission of HIV-1, 353 LANCET 832, 833 (1999).
} 
international community to mobilize against a threat of this magnitude, but somehow there is complacency, even indifference, when there should be resolve and unity. As the toll of the pandemic rises, particularly in the poorest regions, there remains fierce debate about humanitarian assistance, property rights, and ethics.

Given the level of need, there ought to be little disagreement that the more prosperous countries of North America and Europe should be devoting significant resources for education, prevention, and treatment in the poorer countries of Africa and Southeast Asia. Yet, political leaders in developed countries have not viewed it in their self-interest to provide the kind of resources needed. Nor have many leaders in less developed countries given HIV/AIDS the kind of priority necessary to reduce the burden of disease. For complex and not well understood reasons, there has been an absence of political will to confront the HIV/AIDS pandemic.

The private sector has also been unwilling to make the sacrifices necessary to make drugs and potential vaccines available in resource-poor markets. Transnational corporations, often supported by industrialized countries, have used international trade rules to safeguard their proprietary interests in AIDS medicines. This has resulted in higher prices and less access to these essential drugs in developing countries. Certainly, international public health agencies and some pharmaceutical companies have been working to reduce prices and increase access. Yet, most modern medications are still out-of-reach for the poor.

There has even been sharp disagreement among ethicists. Some would require research subjects in the least developed countries to receive the standard of care available in the most developed countries. While this may provide benefits for persons directly participating in research trials, it may not be the best way to study the safety and efficacy of drug regimes that would be affordable in poor countries. This 
disagreement has distracted attention from the vital issue of preventing perinatal transmission in less developed countries by ensuring that women and their infants have access to a range of care and services.

The strategies needed to reduce significantly the burden of HIV/AIDS are well known and demonstrated to be effective. What is still needed are the economic resources and political will necessary to implement comprehensive programs for AIDS prevention and treatment in every region. 